\title{
A Facile Method Using a Flux to Improve Quantum Efficiency of Submicron Particle Sized Phosphors for Solid-State Lighting Applications
}

\author{
Jungmin $\mathrm{Ha}^{1}{ }^{1}$, Ekaterina Novitskaya ${ }^{2}$, Gustavo A. Hirata ${ }^{3}$, Chenhui Zhou ${ }^{4}$, Robyn E. Ridley ${ }^{1}{ }^{1}$, \\ Olivia A. Graeve ${ }^{1,2}$ and Joanna McKittrick 1,2,*D \\ 1 Materials Science and Engineering Program, University of California, San Diego, 9500 Gilman Dr., \\ La Jolla, CA 92093, USA; jungminha@eng.ucsd.edu (J.H.); reridley@ucsd.edu (R.E.R.); \\ ograeve@eng.ucsd.edu (O.A.G.) \\ 2 Department of Mechanical and Aerospace Engineering, University of California, San Diego, \\ 9500 Gilman Dr., La Jolla, CA 92093, USA; eevdokim@ucsd.edu \\ 3 Center for Nanoscience and Nanotechnology, 22860 Ensenada, Mexico; hirata@cnyn.unam.mx \\ 4 Department of Chemical Engineering, University of California, San Diego, 9500 Gilman Dr., La Jolla, \\ CA 92093, USA ; c2zhou@ucsd.edu \\ * Correspondence: jmckittrick@ucsd.edu; Tel.: +1-858-534-5425; Fax: +1-858-534-5698
}

Received: 17 May 2018; Accepted: 6 June 2018; Published: 8 June 2018

\begin{abstract}
This work successfully verified that the addition of a flux $\left(\mathrm{NH}_{4} \mathrm{~F}, \mathrm{NH}_{4} \mathrm{Cl}\right.$, and $\left.\mathrm{H}_{3} \mathrm{BO}_{3}\right)$ during synthesis has an impact on the crystallite size and quantum efficiency of submicron-sized particles of $\mathrm{CaMgSi}_{2} \mathrm{O}_{6}: \mathrm{Eu}^{2+}$ phosphors. The addition of $\mathrm{NH}_{4} \mathrm{~F}$ or $\mathrm{NH}_{4} \mathrm{Cl}$ increased the crystallite size in the submicron-sized particles, yielding an increase in emission intensity and quantum efficiency. On the other hand, the use of the $\mathrm{H}_{3} \mathrm{BO}_{3}$ flux crystallized a secondary phase, $\mathrm{SiO}_{2}$, and changed the lattice parameters, which degraded the luminescent properties. In addition, an excessive amount of $\mathrm{NH}_{4} \mathrm{Cl}$ was examined, resulting in nucleation of a secondary phase, $\mathrm{CaSiO}_{3}$, which changed the lattice parameters with no improvement in luminescent properties. These results demonstrate that the addition of a flux could be a method to improve the quantum efficiency of submicron-sized particles composed of nanocrystallites; however, a judicious choice of the flux composition and amount has to be carefully considered.
\end{abstract}

Keywords: phosphors; $\mathrm{Eu}^{2+}$ activation; flux; quantum efficiency; crystallite size

\section{Introduction}

Powder phosphors produced by the conventional solid-state reaction method have been widely researched for application in near UV-emitting LEDs (nUV-LEDs) [1,2]. This method produces micron-sized powders that have higher quantum efficiencies than smaller-sized powders [3,4], whereas chemical synthesis methods produce submicron-sized powders composed of nanocrystallites. Particle size and crystallite size should be differentiated to understand the quantum efficiency of phosphors. A powder particle can be a single crystal or consist of crystallites, the crystallite size is typically measured by X-ray diffraction or transmission electron microscopy, whereas the particle size is typically measured by dynamic light scattering or scanning electron microscopy. In the remote phosphor configuration, the phosphor particles are on a substrate that is suspended above a nUV-LEDs, as opposed to the conventional configuration where the phosphors are embedded in a polymer around a blue-emitting LED. In addition, in the remote configuration, the packing density of the large particles is low, which generates substantial light scattering [5]. To overcome this issue, phosphors with a small, narrow particle size distribution are required. If the particle radii are $<\sim 400 \mathrm{~nm}$, these particles will 
negligibly scatter visible and near UV radiation, because particle size is smaller than the wavelength of the radiation. However, phosphor particles in the submicron-size regime with nano-sized crystallites have poor quantum efficiency compared to micrometer-sized, single crystal phosphor particles [2,6].

One method that is used to improve the crystallinity and quantum efficiency of micrometer-sized particles is to use a flux [7-9]. A flux material is an inert high-temperature solvent used to accelerate crystallite growth. Generally, $0.5 \mathrm{wt} . \% \sim 10 \mathrm{wt} . \%$ of a flux is used $[8,10]$, forming a thin layer of molten material around crystals during the annealing process and facilitating a high diffusivity path through the flux [10]. Crystals grow in the molten salt solvents, thus normally called flux growth. The process is a well-known method for crystal growth in materials [1,11,12]. A flux is typically used in preparing phosphor powders through a solid-state reaction method, producing regular-shaped particles and enlarged crystallites, which cause the emission intensity to be enhanced [7-9,13-17]. However, this process is rarely researched for nanocrystalline, submicrometer-sized phosphors prepared by wet chemical processes [18-21]. Table 1 shows the effect of various flux compositions on phosphor properties for application in nUV-LED lighting [7-9,13-21]. In each case, the phosphor properties (e.g., quantum efficiency, particle size and surface smoothness) were enhanced with the addition of a flux. In fact, after adding a flux, aluminates and oxides showed enlarged particles and smooth particle surfaces $[7,8,15,18]$, silicates and oxy-nitrides have larger crystallite sizes and regular particle morphology $[14,16,19,20]$. Most importantly, these phosphors all have enhanced emission intensity or quantum efficiencies with the addition of a flux.

A flux is typically mixed with reactants $[7,8,14-16,19]$ or as-synthesized product [20] before an annealing step; thus, is present as the molten phase during the post-synthesis annealing process. Since the flux material should be evaporated after annealing to avoid formation of impurities or second phases in the final product, the melting and boiling temperatures should be considered in relationship to the annealing conditions (temperature, atmosphere), when selecting a flux material. The criteria for selecting a flux are: (1) a low melting temperature, so that it is a liquid during the annealing process [9]; (2) a boiling temperature lower than the annealing temperature, so that the flux can be evaporated to avoid impurity or a second phase formation [13]. Fluxes having a higher boiling temperature than the annealing temperature had been used in most of the previous literature (Table 1); and (3) the difference in ionic radii of the flux and the phosphor elements must be more than $30 \%$ to avoid doping of the flux elements in the phosphors [22]. Chiang et al. [7] reported a formation of a second phase of $\mathrm{BaAl}_{2} \mathrm{O}_{4}$ in $\mathrm{Y}_{2.95} \mathrm{Ce}_{0.05} \mathrm{Al}_{5} \mathrm{O}_{12}$ with a $\mathrm{BaF}$ flux. This suggests that some fluxes can remain after the reaction, producing by-products.

Dai et al. [9] discussed the effect of various fluxes $\left(\mathrm{NH}_{4} \mathrm{Cl}, \mathrm{NH}_{4} \mathrm{~F}, \mathrm{H}_{3} \mathrm{BO}_{3}\right.$, $\mathrm{LiF}$, and $\left.\mathrm{NaF}\right)$ on the emission intensity of $\mathrm{Y}_{1.55} \mathrm{Eu}(\mathrm{III})_{0.45} \mathrm{Ti}_{2} \mathrm{O}_{7}$ phosphors with an orange-red emission under near UV light for display devices such as high-resolution and field emission displays, as well as high-power white light-emitting diodes. It was found that uniform micrometer-sized $(\sim 4 \mu \mathrm{m})$ particles formed with $\mathrm{NaF}$ and $\mathrm{LiF}$ fluxes, and the maximum emission intensity was achieved with $\mathrm{NaF}$ flux, while a narrow size distribution of the particles was not achieved with $\mathrm{NH}_{4} \mathrm{Cl}, \mathrm{NH}_{4} \mathrm{~F}$, or $\mathrm{H}_{3} \mathrm{BO}_{3}$ fluxes. Additionally, Zhang et al. [8] examined the influence of different concentrations of $\mathrm{BaF}_{2}$ flux on the formation of $\mathrm{Ca}_{0.99} \mathrm{Ce}_{0.01} \mathrm{Sc}_{2} \mathrm{O}_{4}$ with green emission prepared by a solid-state reaction. After introducing $\mathrm{BaF}_{2}$, a higher particle growth rate, larger particle sizes, and more narrow particle size distribution were verified, which resulted in improved emission intensity. The emission intensity increased with the increase of the concentration of $\mathrm{BaF}_{2}$ and the maximum emission intensity corresponded to $0.5 \mathrm{wt} . \%$ of $\mathrm{BaF}_{2}$. The emission intensity decreased when the concentration of $\mathrm{BaF}_{2}$ was higher than $0.5 \mathrm{wt} . \%$, which was attributed to particle agglomeration. Wang et al. [20] examined the effect of $\mathrm{Li}_{2} \mathrm{CO}_{3}$ and $\mathrm{K}_{2} \mathrm{CO}_{3}$ fluxes on the formation of $\mathrm{Ca}_{0.68} \mathrm{Mg}_{0.2} \mathrm{Eu}_{0.12} \mathrm{SiO}_{3}$ prepared by a co-precipitation method. The crystallite size increased from $~ 93 \mathrm{~nm}$ to $99 \mathrm{~nm}\left(6 \%\right.$ of $\left.\mathrm{Li}_{2} \mathrm{CO}_{3}\right)$ or to $100 \mathrm{~nm}\left(5 \%\right.$ of $\left.\mathrm{K}_{2} \mathrm{CO}_{3}\right)$, and the quantum efficiencies were improved (from $12 \%$ to $27 \%$ with $\mathrm{Li}_{2} \mathrm{CO}_{3}$ flux and to $31 \%$ with $\mathrm{K}_{2} \mathrm{CO}_{3}$ flux). 
Table 1. Reported results of the addition of flux on phosphor preparation. $\mathrm{T}_{\mathrm{m}}=$ melting temperature, $\mathrm{T}_{\mathrm{b}}=$ boiling temperature, $\Phi=$ quantum efficiency.

\begin{tabular}{|c|c|c|c|c|c|}
\hline Flux $/ \mathrm{T}_{\mathrm{m}} / \mathrm{T}_{\mathrm{b}}\left({ }^{\circ} \mathrm{C}\right)$ & Phosphor Composition & Synthesis Method & Annealing Temperature $\left({ }^{\circ} \mathrm{C}\right)$ & Results & Ref. \\
\hline $\mathrm{CaF}_{2} / 1418 / 2533$ & $\left(\mathrm{Ca}_{0.99} \mathrm{Ce}_{0.01}\right)_{3} \mathrm{Sc}_{2} \mathrm{Si}_{3} \mathrm{O}_{12}$ & Solid state reaction & $1100-1450$ & $\begin{array}{l}\text { Reduced impurities, decreased formation temperature, no reported } \\
\text { crystallite size and } \Phi, \text { emission intensity increased } 2 \times \text {, narrow } \\
\text { particles distribution, removed flux by sublimation after reaction }\end{array}$ & [13] \\
\hline \multirow{4}{*}{$\mathrm{BaF}_{2} / 1368 / 2260$} & $\mathrm{Y}_{2.965} \mathrm{Ce}_{0.035} \mathrm{Al}_{5} \mathrm{O}_{12}$ & Spray pyrolysis & $1300-1600$ & $\begin{array}{l}\text { Enlarged, regular morphology, and non-aggregated particles, } \\
\text { no reported crystallite size and } \Phi \text {, emission intensity increased } 1.4 \times\end{array}$ & [18] \\
\hline & $\mathrm{Y}_{2.95} \mathrm{Ce}_{0.05} \mathrm{Al}_{5} \mathrm{O}_{12}$ & Solid state reaction & $1000-1500$ & $\begin{array}{l}\text { Able to reduce annealing temperature } \mathrm{BaAl}_{2} \mathrm{O}_{4} \text {, byproduct from } \\
\mathrm{BaF}_{2} \text { Spherical shape and smooth surface } \Phi \text { external) increased } 1.3 \times \\
\text { over commercial sample }\end{array}$ & [7] \\
\hline & $\mathrm{Ba}_{0.85} \mathrm{Eu}_{0.15} \mathrm{Si}_{3} \mathrm{Al}_{3} \mathrm{O}_{4} \mathrm{~N}_{5}$ & Solid state reaction & 1550 & $\begin{array}{l}\text { Enlarged crystallite size (no specific number) and particles size, } \\
\text { narrow particles distribution, emission intensity increased slightly, } \\
\text { no reported } \Phi\end{array}$ & [14] \\
\hline & $\mathrm{Ca}_{0.99} \mathrm{Ce}_{0.01} \mathrm{Sc}_{2} \mathrm{O}_{4}$ & Solid state reaction & 1550 and 1450 & $\begin{array}{l}\Phi \text { external) increased } 1.1 \times, \text { no reported crystallite size, enlarged and } \\
\text { regular particles }\end{array}$ & [8] \\
\hline $\mathrm{LiF} / 845 / 1673$ & $\mathrm{Ba}_{0.9} \mathrm{Eu}_{0.1} \mathrm{Mg}_{0.98} \mathrm{Mn}_{0.02} \mathrm{Al}_{10} \mathrm{O}_{17}$ & Molten salt synthesis & $1100-1400$ & $\begin{array}{l}\text { Particles size enlarged, } \mathrm{Li}^{+} \text {into the host lattice analyzed by lattice } \\
\text { parameter, no report crystallite size from XRD, no reported } \Phi, \\
\text { emission intensity increased } 2 \times\end{array}$ & [15] \\
\hline $\mathrm{NaF} / 993 / 1695$ & $\mathrm{Lu}_{2.925} \mathrm{Ce}_{0.075} \mathrm{Al}_{4.79} \mathrm{Si}_{0.21} \mathrm{O}_{11.79} \mathrm{~N}_{0.21}$ & Solid state reaction & 1500 & $\begin{array}{l}\text { Emission intensity increased } 1.3 \times \text {, regular morphology of particles, } \\
\text { no report crystallite size and } \Phi\end{array}$ & [16] \\
\hline $\begin{array}{c}\mathrm{NaF} / 993 / 1695 \\
\mathrm{LiF} / 845 / 1675 \\
\mathrm{H}_{3} \mathrm{BO}_{3} / 171 / 300 \\
\mathrm{NH}_{4} \mathrm{~F} / 100 / \text { decomposes } \\
\end{array}$ & $\mathrm{Y}_{1.55} \mathrm{Eu}_{0.45} \mathrm{Ti}_{2} \mathrm{O}_{7}$ & Solid state reaction & 1350 & $\begin{array}{l}\text { Crystallite size enlarged (no specific number), emission intensity } \\
\text { increased } 11 \times(\mathrm{NaF}), 9 \times(\mathrm{LiF}), 5 \times\left(\mathrm{H}_{3} \mathrm{BO}_{3}\right), 2.5 \times\left(\mathrm{NH}_{4} \mathrm{~F}\right), 39 \% \text { of } \Phi \\
(\mathrm{NaF}) \text {, no reported } \Phi \text { without flux, enlarged particles size }\end{array}$ & [9] \\
\hline $\mathrm{NH}_{4} \mathrm{Cl} / 338 /$ decomposes & $\mathrm{Ba}_{1.488} \mathrm{Sr}_{0.5} \mathrm{Eu}_{0.012} \mathrm{SiO}_{4}$ & Spray pyrolysis & $900-1400$ & $\begin{array}{l}\text { Enlarged particles, enlarged crystallite size (no specific number), no } \\
\text { reported } \Phi, \text { emission intensity increased } 1.3 \times \text {, optimum annealing } \\
\text { temperature decreased }\end{array}$ & [19] \\
\hline $\mathrm{K}_{2} \mathrm{CO}_{3} / 891 /$ decomposes & $\mathrm{Ca}_{0.68} \mathrm{Eu}_{0.12} \mathrm{Mg}_{0.2} \mathrm{SiO}_{3}$ & Co-precipitation & 1200 & $\begin{array}{l}\text { Charge compensation, crystallite size increased } 1.1 \times, \Phi \text { increased } \\
2.5 \times \text {, no phase composition change, no reported particles size }\end{array}$ & {$[20]$} \\
\hline $\mathrm{Li}_{2} \mathrm{CO}_{3} / 734 / 1310$ & $\left(\mathrm{Sr}_{0.92} \mathrm{Eu}_{0.08}\right)_{8} \mathrm{Al}_{12} \mathrm{O}_{24} \mathrm{~S}_{2}$ & Solid state reaction & 900 & $\begin{array}{l}\text { Improved purity, but still impurities remained. No report crystallite } \\
\text { size and } \Phi\end{array}$ & [17] \\
\hline $\mathrm{SrCl}_{2} / 874 / 1250$ & $\mathrm{Sr}_{1.56} \mathrm{Eu}_{0.04} \mathrm{Ba}_{0.4} \mathrm{SiO}_{4}$ & Combustion & $800-950$ & $\begin{array}{l}\text { Crystallite size increased (no specific number), emission intensity } \\
\text { increased } 2.7 \times \text {, no reported } \Phi \text {, similar particles size }\end{array}$ & [21] \\
\hline
\end{tabular}


In this work, blue-emitting $\mathrm{Ca}_{0.94} \mathrm{Eu}_{0.06} \mathrm{MgSi}_{2} \mathrm{O}_{6}$ powders were synthesized through a coprecipitation method $[23,24]$. The powders were annealed with three different fluxes $\left(\mathrm{NH}_{4} \mathrm{~F}, \mathrm{NH}_{4} \mathrm{Cl}\right.$, or $\mathrm{H}_{3} \mathrm{BO}_{3}$ ). In our previous report [24], the $\mathrm{Ca}_{0.94} \mathrm{Eu}_{0.06} \mathrm{MgSi}_{2} \mathrm{O}_{6}$ powders formed submicrometer-sized particles having blue color with $x=0.14$ and $y=0.05$ on the CIE diagram, similar to those defined by the National Television System Committee color $(0.14,0.08)$, but the quantum efficiency was found to be low $(\Phi, \sim 5 \%)$. A low $\Phi$ is a drawback of nanocrystalline-sized phosphors; therefore, the main goal of this study was to improve the $\Phi$ using several different types of flux materials. $\mathrm{NH}_{4} \mathrm{~F}, \mathrm{NH}_{4} \mathrm{Cl}$, and $\mathrm{H}_{3} \mathrm{BO}_{3}$ were selected as flux materials from the reported flux candidates [7-9,13-20] due to their low melting and boiling temperatures (Table 2), which are expected to decompose or evaporate during annealing process. Additionally, the large $(>30 \%)$ ionic radii difference between the flux and the phosphor components indicates that flux contamination of the phosphor is unlikely to occur.

Table 2. Melting and boiling temperature of the fluxes.

\begin{tabular}{|c|c|c|}
\hline Flux & Melting Point $\left({ }^{\circ} \mathrm{C}\right)$ & Boiling Point $\left({ }^{\circ} \mathrm{C}\right)$ \\
\hline $\mathrm{NH}_{4} \mathrm{~F}$ & 100 & Decomposition * \\
\hline $\mathrm{NH}_{4} \mathrm{Cl}$ & 338 & Decomposition ** \\
\hline $\mathrm{H}_{3} \mathrm{BO}_{3}$ & 171 & $300 * * *$ \\
\hline
\end{tabular}

\section{Experimental Procedure}

\subsection{Reagents}

All chemicals were used without further purification and included tetraethyl orthosilicate (TEOS, $99.9 \%$, Sigma Aldrich, St. Louis, $\mathrm{MO}, \mathrm{USA}), \mathrm{Mg}\left(\mathrm{NO}_{3}\right)_{2} \cdot 6 \mathrm{H}_{2} \mathrm{O}(98.3 \%$, Fisher Scientific, Hampton, $\mathrm{NH}, \mathrm{USA}), \mathrm{Ca}\left(\mathrm{NO}_{3}\right)_{2} \cdot 4 \mathrm{H}_{2} \mathrm{O}$ (99.0\%, Macron Fine Chemicals, Center Valley, PA, USA), $\mathrm{Eu}_{2} \mathrm{O}_{3}(99.99 \%$, Alfa Aesar, Haverhill, MA, USA), nitric acid (69.3\%, Fisher Scientific, Hampton, NH, USA), citric acid $\left(\mathrm{C}_{6} \mathrm{H}_{8} \mathrm{O}_{7} \cdot \mathrm{H}_{2} \mathrm{O}\right.$, ACS reagent grade, Macron Fine Chemicals, Center Valley, PA, USA), ethylene glycol $\left(\mathrm{C}_{2} \mathrm{H}_{6} \mathrm{OH}\right.$, certified, Fisher Scientific, Hampton, NJ, USA), polyethylene glycol (PEG, $\mathrm{C}_{2} \mathrm{H}_{4} \mathrm{O} \cdot \mathrm{nH}_{2} \mathrm{O}$, molecular weight $=20,000 \mathrm{~g} / \mathrm{mol}$, Sigma Aldrich, St. Louis, MO, USA), ammonium hydroxide $(28 \sim 30 \%$, $\mathrm{BDH}$ Aristar Plus, Center Valley, PA, USA), $\mathrm{NH}_{4} \mathrm{~F}$ (96\%, Alfa Aesar, Haverhill, MA, USA), $\mathrm{NH}_{4} \mathrm{Cl}$ (ACS reagent grade, Macron Fine Chemicals, Center Valley, PA, USA), and $\mathrm{H}_{3} \mathrm{BO}_{3}(99.5 \%$, Sigma Aldrich, St. Louis, MO, USA).

\subsection{Preparation of $\mathrm{Ca}_{0.94} \mathrm{Eu}_{0.06} \mathrm{MgSi}_{2} \mathrm{O}_{6}$ with and without a Flux}

The co-precipitation method was used to synthesize the powders by following previously reported procedures $[23,24]$. The concentration of 6 at. $\% \mathrm{Eu}^{2+}$ activator was chosen as it is reported to have the highest photoluminescence (PL) emission intensity [24]. Tetraethyl orthosilicate (2.23 $\mathrm{mL}$ ) was added to ethanol $(20 \mathrm{~mL})$ with several drops of nitric acid and deionized water while stirring for $30 \mathrm{~min}$. Meanwhile, $\mathrm{Eu}_{2} \mathrm{O}_{3}(0.0015 \mathrm{~mol})$ was dissolved in nitric acid $(0.4 \mathrm{~mL})$ solution to form aqueous $\mathrm{Eu}\left(\mathrm{NO}_{3}\right)_{3}$ solution. $\mathrm{Mg}\left(\mathrm{NO}_{3}\right)_{2} \cdot 6 \mathrm{H}_{2} \mathrm{O}(0.005 \mathrm{~mol})$ and $\mathrm{Ca}\left(\mathrm{NO}_{3}\right)_{2} \cdot 4 \mathrm{H}_{2} \mathrm{O}(0.0047 \mathrm{~mol})$ were dissolved in deionized water with stirring. After the two nitrate solutions became transparent, all three solutions (tetraethyl orthosilicate, $\mathrm{Eu}\left(\mathrm{NO}_{3}\right)_{2}$, and $\mathrm{Mg}\left(\mathrm{NO}_{3}\right)_{2}$ with $\left.\mathrm{Ca}\left(\mathrm{NO}_{3}\right)_{2}\right)$ were mixed together and then stirred for $1 \mathrm{~h}$. Subsequently, ammonium hydroxide was added dropwise into the solution to reach a $\mathrm{pH}$ of 10 and initiate precipitation. White precipitates were formed, and the suspension was stirred for $8 \mathrm{~h}$. Next, $\mathrm{NH}_{4} \mathrm{~F}, \mathrm{NH}_{4} \mathrm{Cl}$, or $\mathrm{H}_{3} \mathrm{BO}_{3}$ was added to the solution at amounts of $2 \mathrm{wt} . \%, 6 \mathrm{wt} \%$, or $10 \mathrm{wt} . \%$ of $\mathrm{Ca}_{0.94} \mathrm{Eu}_{0.06} \mathrm{MgSi}_{2} \mathrm{O}_{6}$. The conversion of wt.\% to mol. \% for each flux is shown in Table 3 . The solutions were then centrifuged and dried at $80^{\circ} \mathrm{C}$ for $12 \mathrm{~h}$. Finally, a post-synthesis annealing step was performed at $1100{ }^{\circ} \mathrm{C}$ for $2 \mathrm{~h}$ in air and then at $1100{ }^{\circ} \mathrm{C}$ for $4 \mathrm{~h}$ in a $5 \% \mathrm{H}_{2} / 95 \% \mathrm{~N}_{2}$ atmosphere to transform $\mathrm{Eu}^{3+}$ to $\mathrm{Eu}^{2+}$. 
Table 3. Conversion of wt. \% to mol.\% for each flux in the solid phosphor powders.

\begin{tabular}{cccc}
\hline wt.\% Flux & $\mathrm{NH}_{\mathbf{4}} \mathrm{F}$ (mol.\%) & $\mathrm{NH}_{\mathbf{4}} \mathrm{Cl}$ (mol.\%) & $\mathrm{H}_{\mathbf{3}} \mathrm{BO}_{3}$ (mol.\%) \\
\hline $\mathbf{2}$ & 12 & 8 & 7 \\
$\mathbf{6}$ & 28 & 22 & 19 \\
$\mathbf{1 0}$ & 40 & 31 & 28 \\
\hline
\end{tabular}

\subsection{Characterization}

The powders were analyzed by X-ray diffraction (XRD) on a D2 Phaser (Bruker, Karlsruhe, Germany) using $\mathrm{CuK} \alpha$ radiation and a step size of $0.014^{\circ}$ over a $2 \theta$ range of 20 to $80^{\circ}$. The crystallite sizes, lattice parameters, and ratio of the phases presented were calculated by Rietveld refinement using the TOPAS 4.2 software (Bruker). The sizes of the powders were examined by dynamic light scattering (DLS) on a Nanotrac Wave II system (Microtrac Inc., York, PA, USA) [25-27]. Particles were distributed in an aqueous solution by sonication in a water bath for DLS experiments. A field emission scanning electron microscope (FESEM, XL30, Philips, Amsterdam, Netherlands) at $10 \mathrm{keV}$ was used to image the powders to confirm sizes and determine morphology. Samples were coated with iridium at $85 \mu \mathrm{A}$ for $10 \mathrm{~s}$ before imaging. Energy dispersive spectroscopic analysis (EDS) was performed with a scanning electron microscope (Apreo SEM, FEI, Hillsboro, OR, USA) to analyze the concentration of elements. Absolute quantum efficiency $(\Phi)$ measurements were performed using an integrating sphere system, with sodium salicylate $(\Phi=44 \%)$ as a reference standard. PL emission and excitation spectra were acquired with a fluorescence spectrophotometer (Hitachi F-7000, Hitachi High-Technologies Corporation, Tokyo, Japan) using $\lambda=350 \mathrm{~nm}$ excitation wavelength (pulse $=0.025 \mathrm{~s}$ ). This excitation wavelength was selected as it produced the highest PL emission intensity for $\mathrm{Ca}_{0.94} \mathrm{Eu}_{0.06} \mathrm{MgSi}_{2} \mathrm{O}_{6}$ [24] .

\section{Results and Discussion}

\subsection{Crystal Structure and Lattice Parameters}

Figure 1 shows the crystal structure of $\mathrm{CaMgSi}_{2} \mathrm{O}_{6}$. Also known as diopside, it has a monoclinic crystal structure with space group C2/c. The lattice parameters are $a=0.9743 \mathrm{~nm}, b=0.8879 \mathrm{~nm}$, $c=0.5230 \mathrm{~nm}$, and $\beta=105.53^{\circ}$ [24]. The coordination numbers for $\mathrm{Ca}^{2+}, \mathrm{Mg}^{2+}$, and $\mathrm{Si}^{4+}$ of 8,6 , and 4 , respectively. The ionic radii of the ions are listed in Table 4 . The radii differences between ions in $\mathrm{CaMgSi}_{2} \mathrm{O}_{6}$ and the flux are $\mathrm{Mg}^{2+}-\mathrm{B}^{3+}=90 \%, \mathrm{Si}^{4+}-\mathrm{B}^{3+}=81 \%, \mathrm{O}^{2-}-\mathrm{F}^{-}=5 \%$ (4-coordinated, 6-coordinated), $\mathrm{O}^{2-}-\mathrm{Cl}^{-}=26 \%$ (6-coordinated). The $\mathrm{F}^{-}$from $\mathrm{NH}_{4} \mathrm{~F}$ and $\mathrm{Cl}^{-}$from $\mathrm{NH}_{4} \mathrm{Cl}$ are likely to be composed to $\mathrm{HF}(\mathrm{g})$ and $\mathrm{HCl}(\mathrm{g})$ during the annealing process (Table 2) although the radii difference between $\mathrm{O}^{2-}$ and $\mathrm{F}^{-}$/or $\mathrm{Cl}^{-}$is less than $30 \%$. $\mathrm{H}^{+}$may occupy interstitial sites in the lattice because of its small size. $\mathrm{Eu}^{3+}\left(0.107 \mathrm{~nm}\right.$ for 8-coordinated) is expected to occupy the $\mathrm{Ca}^{2+}$ sites due to the radii size similarity ( $5 \%$ difference) before reduction annealing and transforms to $\mathrm{Eu}^{2+}$ after reduction.

Table 4. The ionic radii (nm) of ions of in $\mathrm{CaMgSi}_{2} \mathrm{O}_{6}$ and fluxes, $\mathrm{NH}_{4} \mathrm{~F}, \mathrm{NH}_{4} \mathrm{Cl}_{1} \mathrm{H}_{3} \mathrm{BO}_{3}$.

\begin{tabular}{cccc}
\hline Ions & 4-Coordinated & 6-Coordinated & 8-Coordinated \\
\hline $\mathbf{C a}^{2+}$ & - & - & 0.112 \\
$\mathbf{M g}^{2+}$ & - & 0.072 & - \\
$\mathbf{S i}^{4+}$ & 0.026 & - & - \\
$\mathbf{O}^{2-}$ & 0.138 & 0.140 & 0.142 \\
$\mathbf{B}^{3+}$ & 0.011 & 0.027 & - \\
$\mathbf{F}^{-}$ & 0.131 & 0.133 & - \\
$\mathbf{C l}^{-}$ & - & 0.181 & - \\
\hline
\end{tabular}




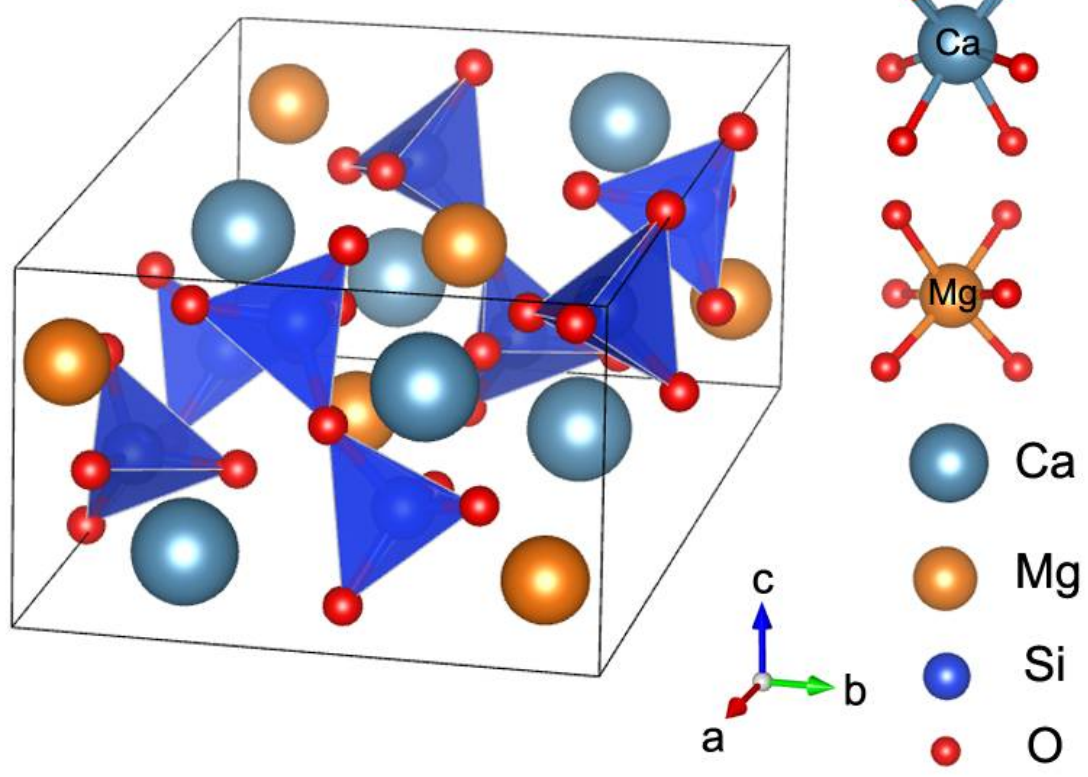

(a)

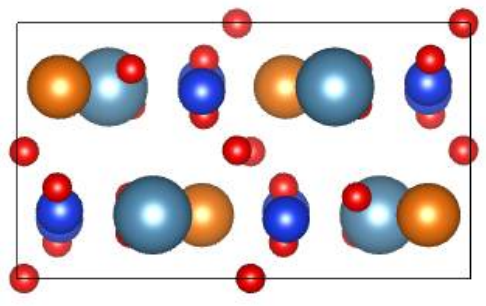

$\varliminf_{a b}^{c}$ (b)

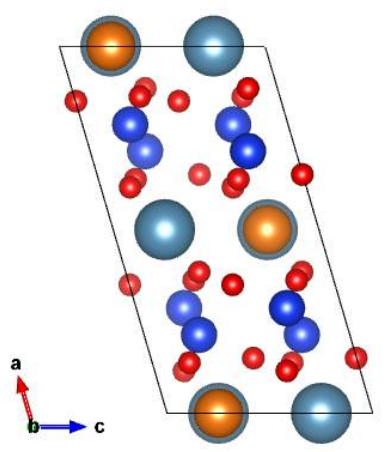

(c)

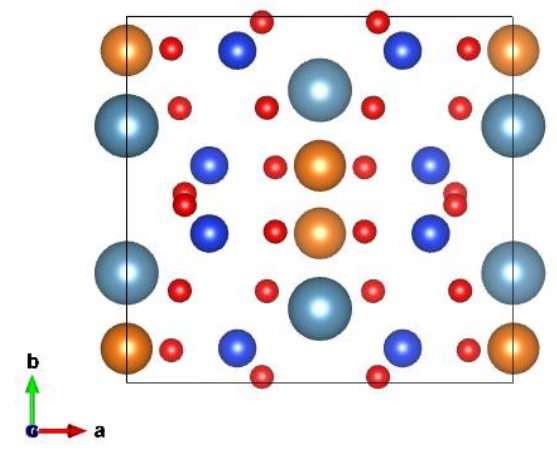

(d)

Figure 1. The crystal structure of $\mathrm{CaMgSi}_{2} \mathrm{O}_{6}$ : (a) 3-D unit cell representation; (b) along the [100]; (c) along the [010]; and (d) along the [001] drawn by VESTA (Visualization for Electronic and Structural Analysis) [28].

XRD patterns of $\mathrm{Ca}_{0.94} \mathrm{Eu}_{0.06} \mathrm{MgSi}_{2} \mathrm{O}_{6}$ with and without $\mathrm{NH}_{4} \mathrm{~F}$ and $\mathrm{NH}_{4} \mathrm{Cl}$ fluxes are shown in Figure 2. The peak widths narrowed with an increase in the concentration of $\mathrm{NH}_{4} \mathrm{~F}$ (Figure 2a), indicating an increase in crystallite size. Several small peaks from $\mathrm{CaEu}_{4}\left(\mathrm{SiO}_{4}\right)_{3} \mathrm{O}$ were recorded for 10 wt.\% $\mathrm{NH}_{4} \mathrm{~F}$. $\mathrm{CaEu}_{4}\left(\mathrm{SiO}_{4}\right)_{3} \mathrm{O}$ was previously identified in $\mathrm{Ca}_{0.94} \mathrm{Eu}_{0.06} \mathrm{MgSi}_{2} \mathrm{O}_{6}$ under annealing temperature of $1247^{\circ} \mathrm{C}$ [29], which is a higher temperature than used in the present study, with no flux. As shown previously, a flux can decrease the temperature for the crystallization of phosphor materials $[7,13]$, so that excessive $\mathrm{NH}_{4} \mathrm{~F}$ may lead to the new formation of $\mathrm{CaEu}_{4}\left(\mathrm{SiO}_{4}\right)_{3} \mathrm{O}$ at the lower temperature by reducing the corresponding formation temperature. For the diffraction patterns from the powders prepared using $\mathrm{NH}_{4} \mathrm{Cl}$ flux, shown in Figure $2 \mathrm{~b}$, the peak width also slightly narrowed with the increase of concentration of $\mathrm{NH}_{4} \mathrm{Cl}$. However, this narrowing is less pronounced in comparison with the $\mathrm{NH}_{4} \mathrm{~F}$, indicating that the crystallite sizes with $\mathrm{NH}_{4} \mathrm{~F}$ flux were larger. The crystallite sizes for different concentrations of $\mathrm{NH}_{4} \mathrm{~F}$ and $\mathrm{NH}_{4} \mathrm{Cl}$ fluxes are shown in Figure 2c. For the $\mathrm{NH}_{4} \mathrm{~F}$ flux, the crystallite size increased from roughly $13 \mathrm{~nm}$ with no flux to about $31 \mathrm{~nm}$ with $10 \mathrm{wt} . \% \mathrm{NH}_{4} \mathrm{~F}$. The maximum crystallite size for $\mathrm{NH}_{4} \mathrm{Cl}$ flux was about $19 \mathrm{~nm}$ with $2 \mathrm{wt} . \% \mathrm{NH}_{4} \mathrm{Cl}$. Different diffusion rates of the reactants through a flux may explain why the material produced with 
$\mathrm{NH}_{4} \mathrm{~F}$ flux shows enlarged crystallite sizes compared to that made with $\mathrm{NH}_{4} \mathrm{Cl}$ flux. Ions move through liquid flux during the annealing process with a diffusion coefficient expressed by $D=(1 / f) \cdot \mathrm{kT}$, where $f$ is the frictional coefficient, $\mathrm{k}$ is the Boltzmann's constant, and $\mathrm{T}$ is the absolute temperature. The frictional coefficient can be expressed by $f=\pi \mu r$, where $\mu$ is viscosity and $r$ is the radius of the ion. Therefore, a relationship $D \propto 1 / r$ is found. $\mathrm{F}^{-}(0.119 \mathrm{~nm})$ is smaller than $\mathrm{Cl}^{-}(0.167 \mathrm{~nm})$, therefore $\mathrm{NH}_{4} \mathrm{~F}$ may act as a more effective flux compared to $\mathrm{NH}_{4} \mathrm{Cl}$ from the point of view of enhanced diffusivity, assuming equivalent viscosities.

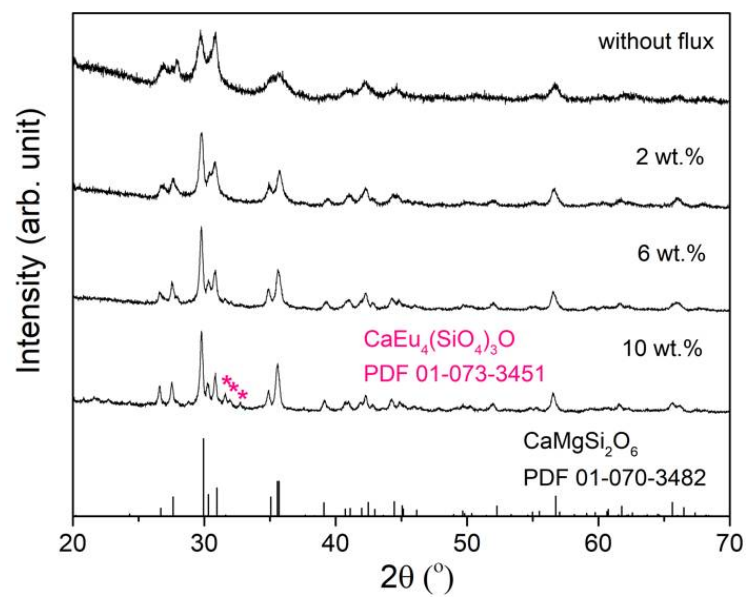

(a)

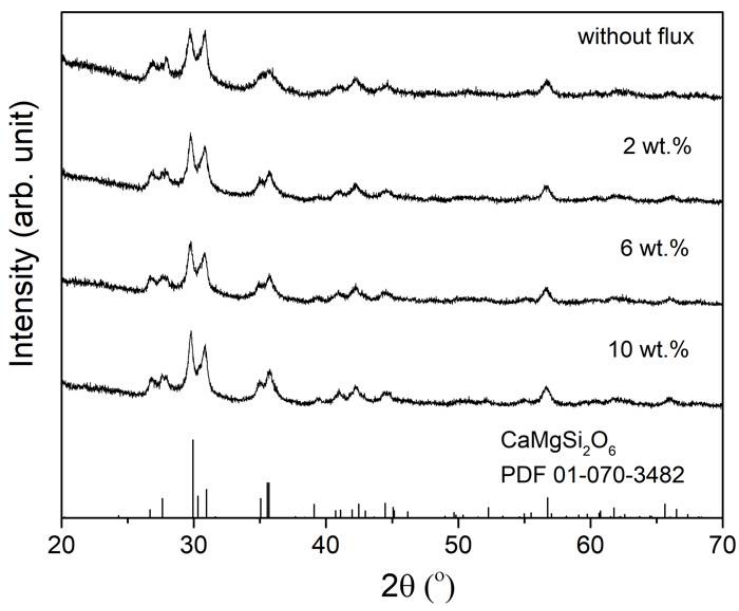

(b)

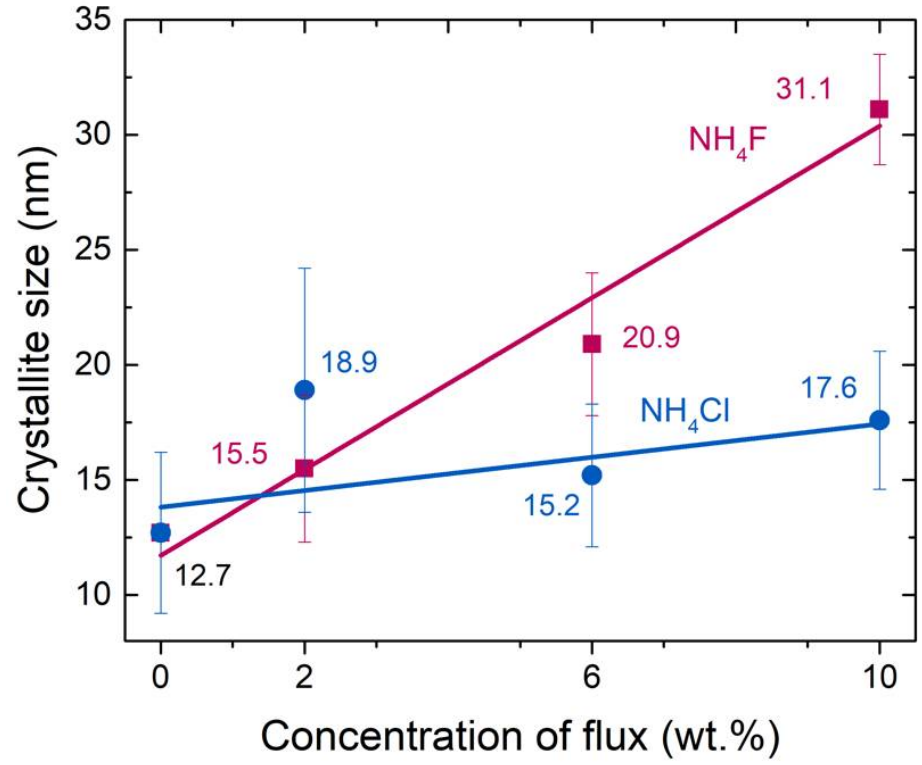

(c)

Figure 2. X-ray diffraction patterns of $\mathrm{Ca}_{0.94} \mathrm{Eu}_{0.06} \mathrm{MgSi}_{2} \mathrm{O}_{6}$ with a flux of (a) $\mathrm{NH}_{4} \mathrm{~F}$ and $(\mathbf{b}) \mathrm{NH}_{4} \mathrm{Cl}$.

(c) Calculated crystallite sizes of $\mathrm{Ca}_{0.94} \mathrm{Eu}_{0.06} \mathrm{MgSi}_{2} \mathrm{O}_{6}$ with $\mathrm{NH}_{4} \mathrm{~F}$ and $\mathrm{NH}_{4} \mathrm{Cl}$ fluxes.

With the $\mathrm{H}_{3} \mathrm{BO}_{3}$ flux, $\mathrm{SiO}_{2}$ impurities were detected, as shown in the XRD patterns in Figure 3a. Even though $\mathrm{B}^{3+}$ and $\mathrm{Si}^{4+}$ have quite different ionic radii $(0.026 \mathrm{~nm}$ and $0.011 \mathrm{~nm}$ ) [30], a substitution of $\mathrm{B}^{3+}$ on $\mathrm{Si}^{4+}$ sites on the tetrahedral site has been previously reported [31,32] although there is a charge difference between $\mathrm{B}^{3+}$ and $\mathrm{Si}^{4+}$. Marler et al. [31] reported synthetic tourmaline (olenite) to replace partial silicon ions with excessive boron ions; and the difference in charge between $\mathrm{Si}^{4+}$ and $\mathrm{B}^{3+}$ was compensated by protons leading to the unusually high water content. Xia et al. [32] studied $\mathrm{La}_{5}\left(\mathrm{Si}_{2-\mathrm{x}} \mathrm{B}_{1-\mathrm{x}}\right)\left(\mathrm{O}_{13-\mathrm{x}} \mathrm{N}_{\mathrm{x}}\right): \mathrm{Ce}^{3+}$ by replacing partially $\mathrm{B}^{3+}-\mathrm{O}^{2-}$ by the $\mathrm{Si}^{4+}-\mathrm{N}^{3-}$; and the 
charge difference from the replacement of $\mathrm{B}^{3+}$ by $\mathrm{Si}^{4+}$ was compensated by the substitution of $\mathrm{O}^{2-}$ by $\mathrm{N}^{3-}$. In the current study, the charge difference from the partial replacement of $\mathrm{Si}^{4+}$ by $\mathrm{B}^{3+}$ could be compensated to produce oxygen vacancies due to no other ion replacements.

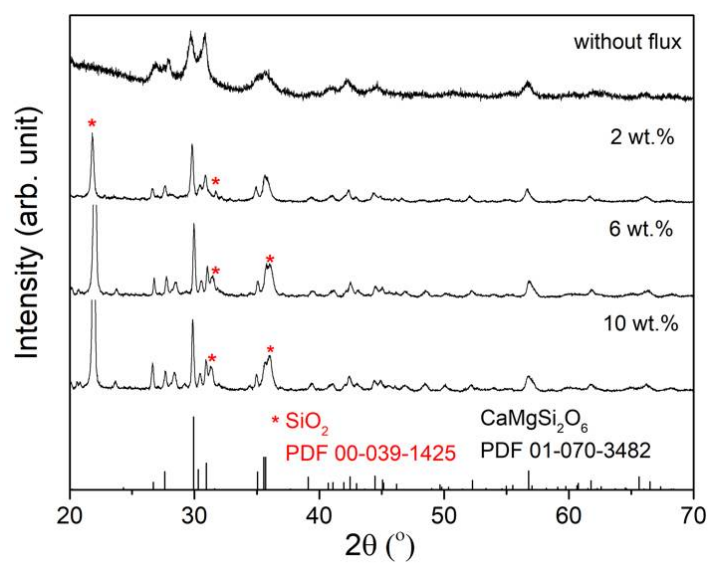

(a)

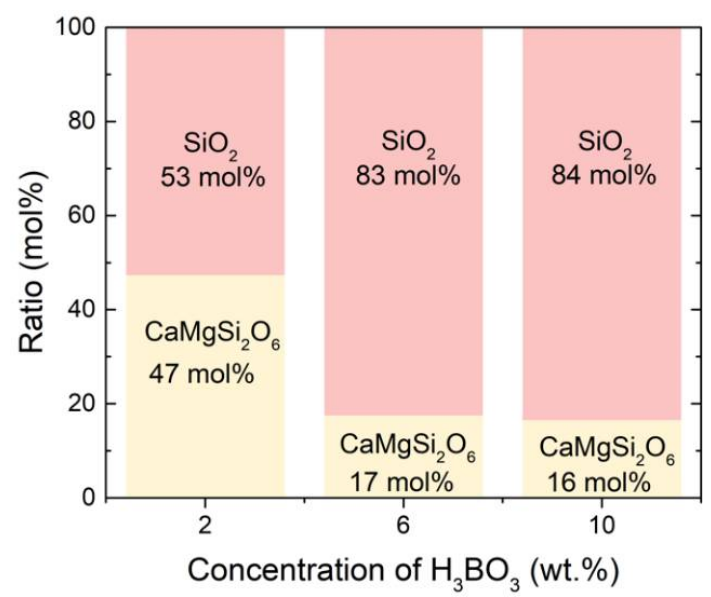

(b)

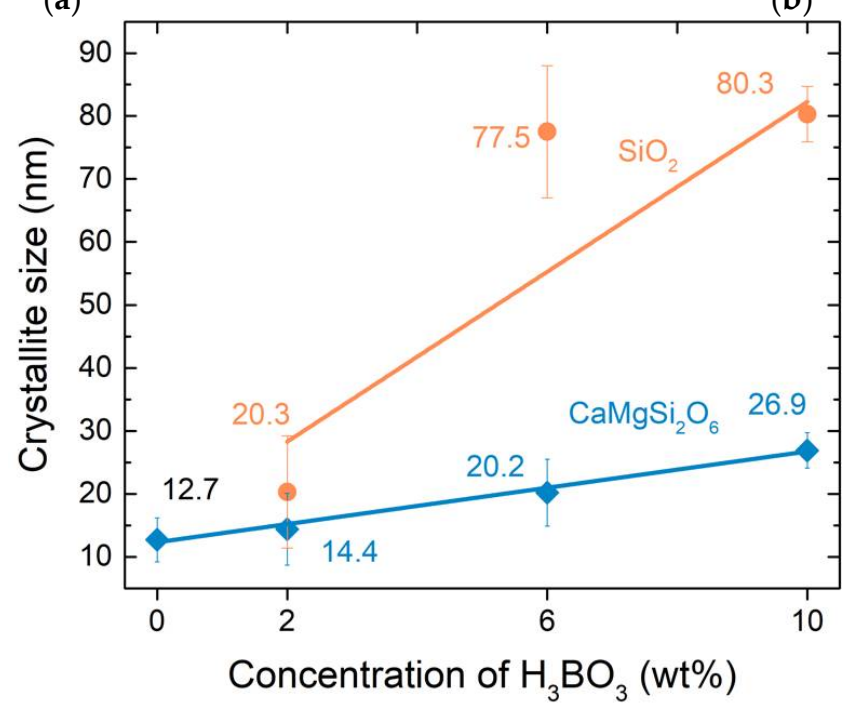

(c)

Figure 3. (a) X-ray diffraction patterns of $\mathrm{Ca}_{0.94} \mathrm{Eu}_{0.06} \mathrm{MgSi}_{2} \mathrm{O}_{6}$ with $\mathrm{H}_{3} \mathrm{BO}_{3}$ flux; (b) Calculated molar ratios of the phases present and (c) calculated crystallite sizes.

With an assumption that B ions partially replace the $\mathrm{Si}$ ions, the corresponding chemical reaction is:

$$
\mathrm{CaMgSi}_{2} \mathrm{O}_{6}+\mathrm{xH}_{3} \mathrm{BO}_{3} \rightarrow \mathrm{CaMg}\left(\mathrm{Si}_{1-\mathrm{x} / 2} \mathrm{~B}_{\mathrm{x} / 2}\right)_{2} \mathrm{O}_{6}+\mathrm{xSiO} 2+\mathrm{xH}_{2} \mathrm{O}+\mathrm{x} / 2 \mathrm{H}_{2} \text {. }
$$

As the amount of $\mathrm{H}_{3} \mathrm{BO}_{3}$ increased (2-10 wt.\%), the corresponding amount of $\mathrm{SiO}_{2}$ increased (53-84 mol.\%, Figure 3b). The crystallite size of the phosphor increased from $\sim 13 \mathrm{~nm}$ to $\sim 27 \mathrm{~nm}$, while for $\mathrm{SiO}_{2}$ it increased from $20 \mathrm{~nm}$ to $80 \mathrm{~nm}$ (Figure 3c).

The calculated lattice parameters of $\mathrm{Ca}_{0.94} \mathrm{Eu}_{0.06} \mathrm{MgSi}_{2} \mathrm{O}_{6}$ with and without each flux are shown in Figure 4. The lattice parameters of powders prepared with $\mathrm{NH}_{4} \mathrm{~F}$ and $\mathrm{NH}_{4} \mathrm{Cl}$ (Figure $4 a, b$ ) were identical to the phosphors prepared without flux, indicating that these two fluxes did not affect the crystal structure of the resultant materials. In contrast, with $\mathrm{H}_{3} \mathrm{BO}_{3}$ flux, the $b$ and $c$ parameters did not show significant change, while $a$ decreased from $0.9743 \mathrm{~nm}$ to $0.9670 \mathrm{~nm}$. This is presumably due to the substitution of $\mathrm{B}^{3+}(0.011 \mathrm{~nm})$ with $\mathrm{Si}^{4+}(0.036 \mathrm{~nm})$ sites, causing the lattice parameter to decrease. Vegard's law [33], which is an empirical rule based on a linear relationship found between 
lattice parameters and the size of the constituent elements. The formation of $\frac{1}{2} \mathrm{O}$ vacancies from the charge difference between $\mathrm{Si}^{4+}$ and $\mathrm{B}^{3+}$ can affect the lattice parameters. Therefore, the relationship between the initial lattice parameter and the one with $\mathrm{B}^{3+}$ is $a=a_{0}-x\left(r_{S i}-r_{B}\right)-\frac{1}{2} x r_{O}$, where $a$ is the lattice parameter $(0.9670 \mathrm{~nm})$ with $10 \mathrm{wt} . \% B^{3+}$ addition, $a_{0}$ is the initial lattice parameter $(0.9743 \mathrm{~nm})$, $x$ is the partial substitution of $\mathrm{B}$ on $\mathrm{Si}, r_{S i}, r_{B}, r_{O}$ are the radii of $\mathrm{Si}^{4+}, \mathrm{B}^{3+}$, and $\mathrm{O}^{2-}$, respectively. The $x$ value obtained is 0.09 , which is smaller than the molar fraction of $\mathrm{H}_{3} \mathrm{BO}_{3}$ added ( 0.28 converted from $10 \mathrm{wt} . \% \mathrm{H}_{3} \mathrm{BO}_{3}$ ). The excess $\mathrm{B}^{3+}$ was not detected in the XRD patterns (detection limit of $3 \sim 5 \mathrm{wt} . \%$ ). Therefore, due to the low boiling temperatures, it likely does not remain in the resultant powder. The change of lattice parameter $a$, while parameters $b$ and $c$ remain unchanged, can be explained by the ion arrangement. Along the [100] and [001] directions (see Figure $1 \mathrm{~b}, \mathrm{~d}$ ), there are two $\mathrm{Si}^{4+}$ along the $a$-axis, four along the $b$-axis, and three along $c$-axis. The fractions of one $\mathrm{Si}^{4+}$ along the $a-, b$-, and $c$-axes are $0.50,0.25$, and 0.33 , respectively. The fraction of $\mathrm{Si}^{4+}$ along the $a$-axis is the largest, so that the replacement of $\mathrm{Si}^{4+}$ is affected more along this axis, resulting in a decrease of $a$ with an addition of $10 \mathrm{wt} . \% \mathrm{H}_{3} \mathrm{BO}_{3}$. Another possible reason for a change in lattice parameter of $\mathrm{Ca}_{0.94} \mathrm{Eu}_{0.06} \mathrm{MgSi}_{2} \mathrm{O}_{6}$ is $\mathrm{H}^{+}$dissolved in interstitial sites, but this would cause an increase of lattice parameters, which was not observed.

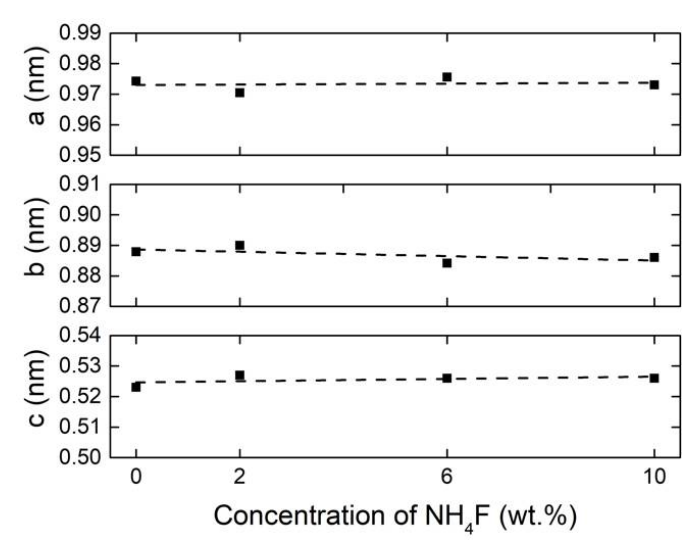

(a)

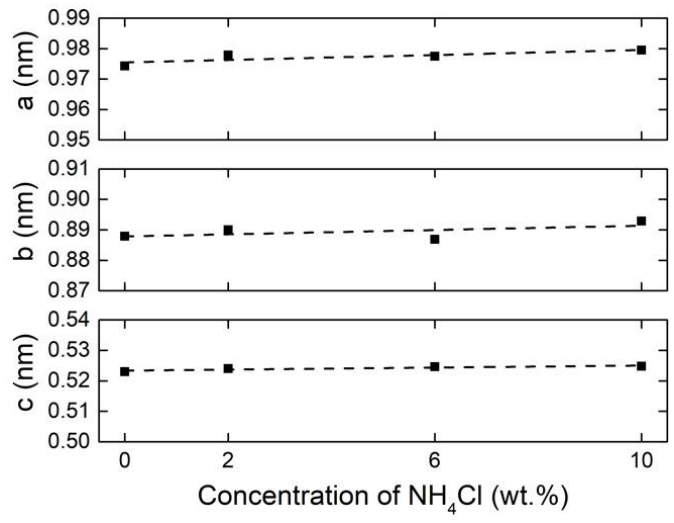

(b)

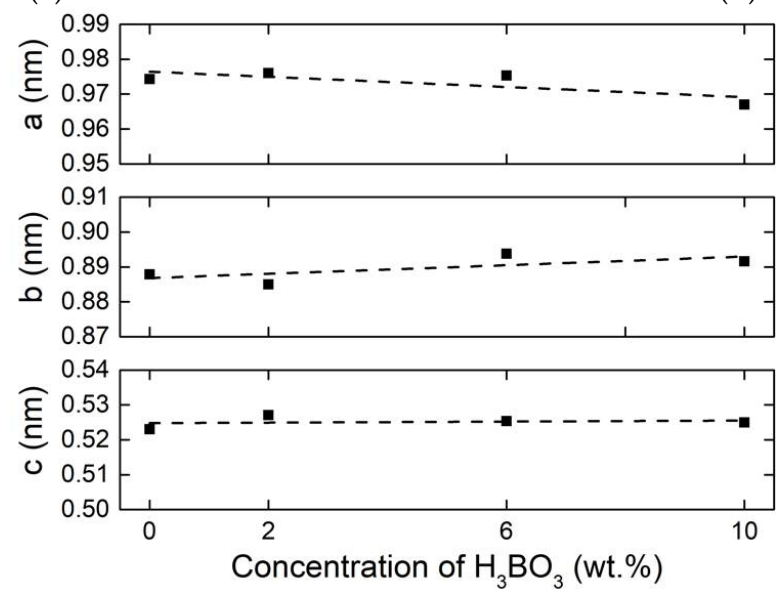

(c)

Figure 4. Calculated lattice parameters of $\mathrm{Ca}_{0.94} \mathrm{Eu}_{0.06} \mathrm{MgSi}_{2} \mathrm{O}_{6}$ from the $\mathrm{X}$-ray diffraction results with a flux of (a) $\mathrm{NH}_{4} \mathrm{~F}$; (b) $\mathrm{NH}_{4} \mathrm{Cl}$; and (c) $\mathrm{H}_{3} \mathrm{BO}_{3}$.

\subsection{Scanning Electron Microscopy and Dynamic Lighting Scattering Analysis}

SEM images of $\mathrm{Ca}_{0.94} \mathrm{Eu}_{0.06} \mathrm{MgSi}_{2} \mathrm{O}_{6}$ are shown in Figure $5 \mathrm{a}$ for no flux, Figure $5 \mathrm{~b}-\mathrm{d}$ for $\mathrm{NH}_{4} \mathrm{~F}$ flux addition, Figure 5e-g for $\mathrm{NH}_{4} \mathrm{Cl}$ flux addition, and Figure $5 \mathrm{~h}-\mathrm{j}$ for $\mathrm{H}_{3} \mathrm{BO}_{3}$ flux addition. For $\mathrm{NH}_{4} \mathrm{~F}$ or $\mathrm{NH}_{4} \mathrm{Cl}$ fluxes, the particle sizes and morphologies were similar to those without a flux. However, 
the particles with the $\mathrm{H}_{3} \mathrm{BO}_{3}$ flux were aggregated, and the particle sizes were irregular. From EDS analysis, the ratio of Ca:Mg:Si:O was 1:1:7:13 in the large particles (yellow point in Figure 5h), where the amounts of $\mathrm{Si}$ and $\mathrm{O}$ are two to three times more than those of $\mathrm{CaMgSi}_{2} \mathrm{O}_{6}(\mathrm{Ca}: \mathrm{Mg}: \mathrm{Si}: \mathrm{O}=1: 1: 2: 6)$. In the small particles (red point in Figure 5h), the ratio of Ca:Mg:Si:O was 1:1:3:5, which is closer to that of $\mathrm{CaMgSi}_{2} \mathrm{O}_{6}$. Although the results from EDS are considered more accurate for polished surfaces than the powders, the ratio of $\mathrm{Ca}, \mathrm{Mg}, \mathrm{Si}, \mathrm{O}$ demonstrated differences between small and large particles. Also, given that the EDS analysis penetrates 1-2 $\mu \mathrm{m}$ below the surface [34], $\mathrm{CaMgSi}_{2} \mathrm{O}_{6}$ could be detected under the $\mathrm{SiO}_{2}$ particles, which could be the reason EDS analysis showed a small amount of $\mathrm{Ca}$ and $\mathrm{Mg}$, when presumably large $\mathrm{SiO}_{2}$ particles were analyzed. Therefore, large particles can be considered as $\mathrm{SiO}_{2}$ and the aggregated, small particles as $\mathrm{CaMgSi}_{2} \mathrm{O}_{6}$.

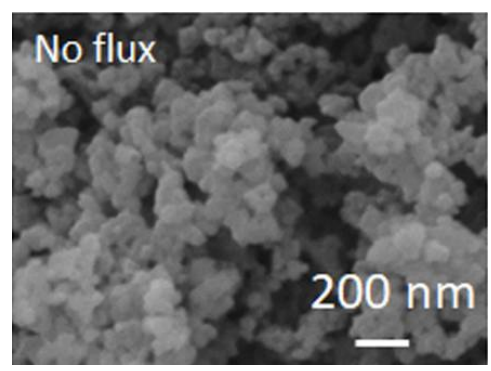

(a)

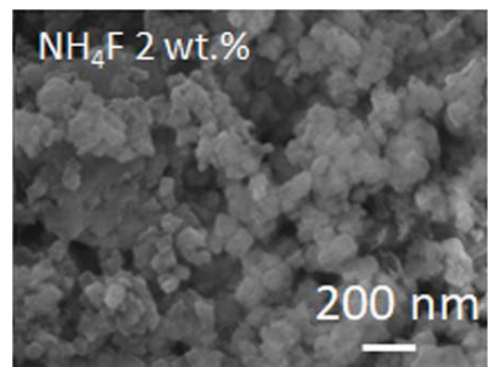

(b)

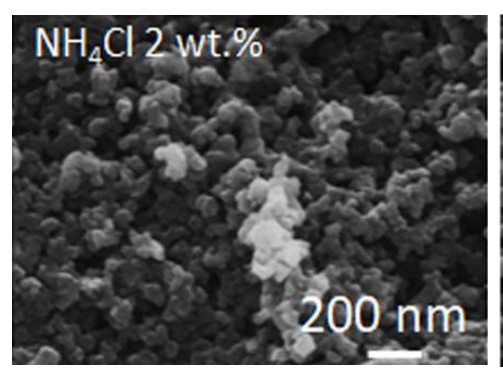

(e)

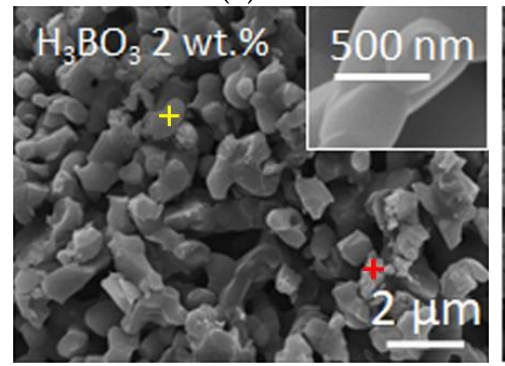

(h)

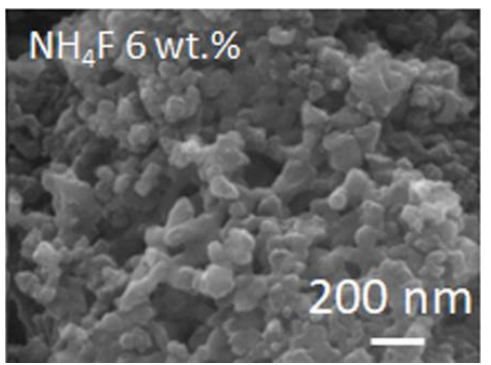

(c)

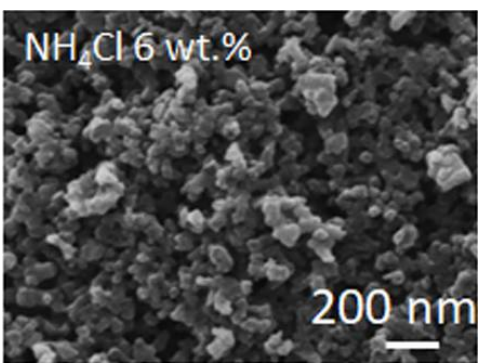

(f)

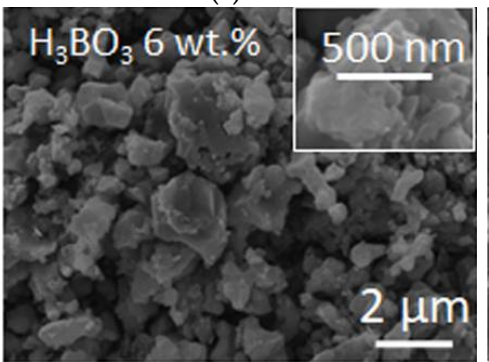

(i)

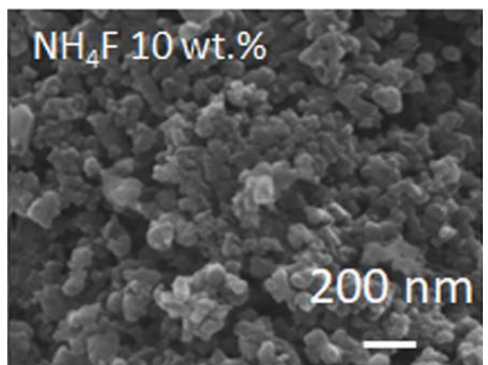

(d)

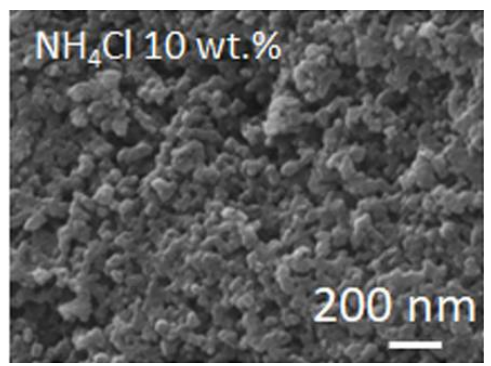

(g)

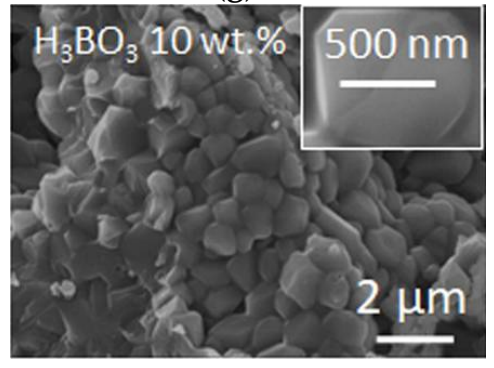

(j)

Figure 5. Scanning electron microscopy images of $\mathrm{Ca}_{0.94} \mathrm{Eu}_{0.06} \mathrm{MgSi}_{2} \mathrm{O}_{6}$. Without any flux (a) taken from [24]. With $\mathrm{NH}_{4} \mathrm{~F}$ flux (b) 2 wt.\%, (c) 6 wt.\%, and (d) 10 wt.\%. With $\mathrm{NH}_{4} \mathrm{Cl}$ flux: (e) 2 wt.\%, (f) 6 wt. $\%$, and (g) 10 wt.\%. With $\mathrm{H}_{3} \mathrm{BO}_{3}$ flux: (h) 2 wt. $\%$, (i) 6 wt. $\%$, (j) 10 wt. $\%$. 
From the DLS analysis (Figure 6), the average particle sizes were $83 \mathrm{~nm}$ for powders without flux. With the $\mathrm{NH}_{4} \mathrm{~F}$ flux, the average particles sizes were $80 \mathrm{~nm}(2 \mathrm{wt} . \%), 100 \mathrm{~nm}(6 \mathrm{wt} . \%)$, and $133 \mathrm{~nm}$ (10 wt.\%), respectively. For the $\mathrm{NH}_{4} \mathrm{Cl}$ flux, the corresponding particle sizes were found to be $84 \mathrm{~nm}$ ( $2 \mathrm{wt.} \%), 82 \mathrm{~nm}(6 \mathrm{wt} . \%)$, and $118 \mathrm{~nm}(10 \mathrm{wt.} \%)$. Overall, this indicates that particles were still submicron-sized with the addition of flux. However, some studies reported uniformly shaped and enlarged particles with up to $14 \mathrm{wt} . \%$ of flux addition $[8,14,15,19]$. For the $\mathrm{H}_{3} \mathrm{BO}_{3}$ flux, the average particle sizes were $307 \mathrm{~nm}$ ( $2 \mathrm{wt.} \%), 318 \mathrm{~nm}(6 \mathrm{wt} . \%)$, and $375 \mathrm{~nm}(10 \mathrm{wt} . \%)$, which resulted from an increase in the amount of the $\mathrm{SiO}_{2}$ particles.

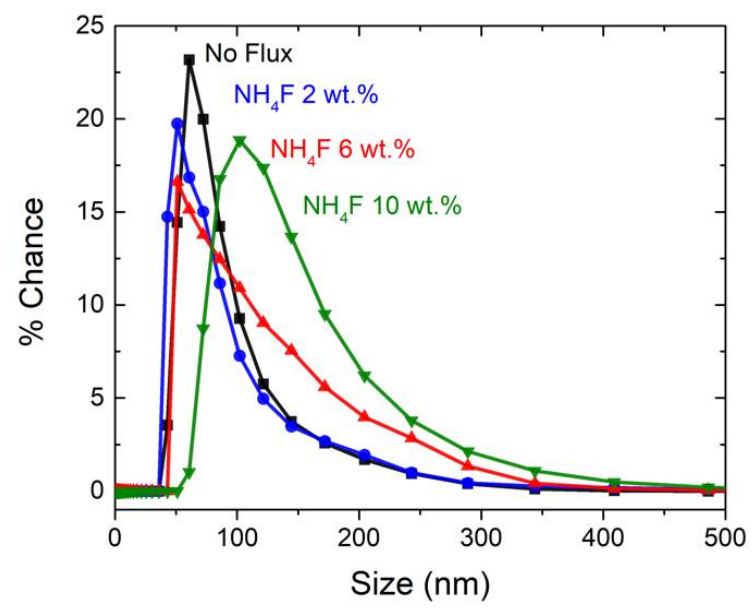

(a)

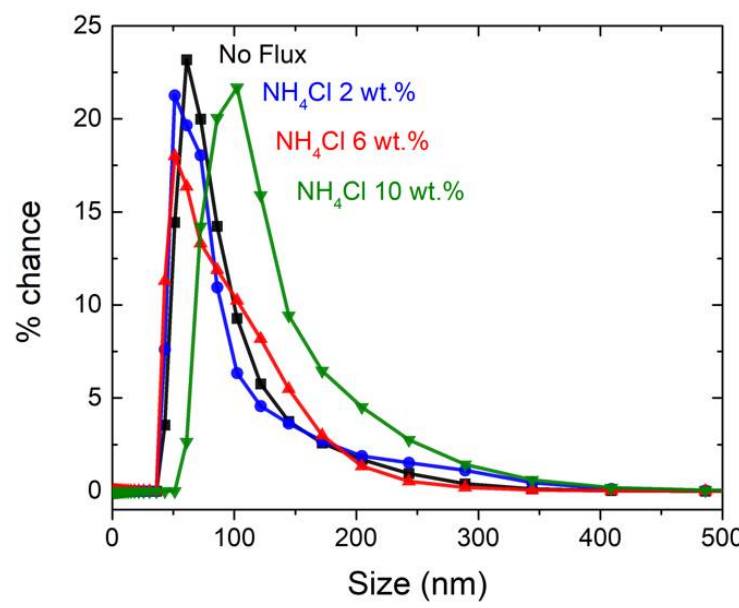

(b)

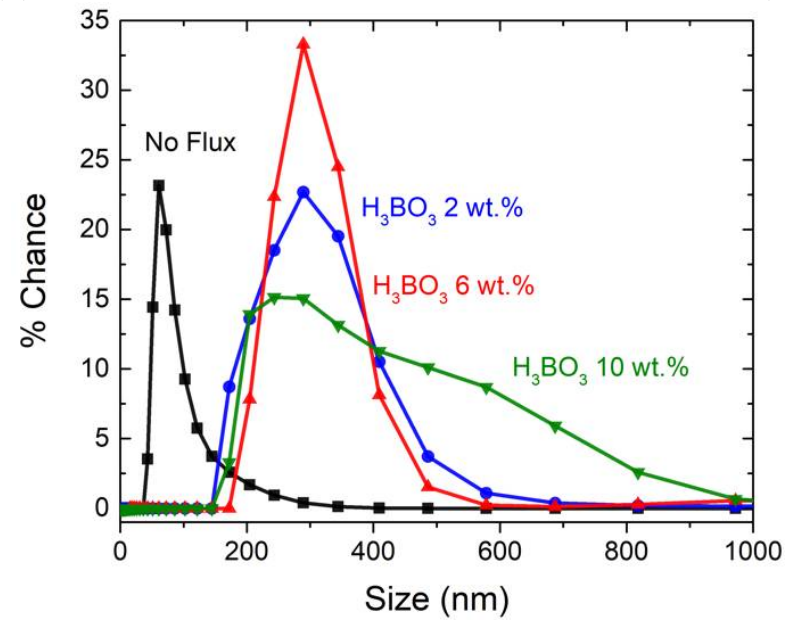

(c)

Figure 6. The distributions of particle sizes of $\mathrm{Ca}_{0.94} \mathrm{Eu}_{0.06} \mathrm{MgSi}_{2} \mathrm{O}_{6}$ with fluxes (a) $\mathrm{NH}_{4} \mathrm{~F} ;(\mathbf{b}) \mathrm{NH}_{4} \mathrm{Cl}$ and $(\mathrm{c}) \mathrm{H}_{3} \mathrm{BO}_{3}$ analyzed by dynamic light scattering analysis.

\subsection{Photoluminescence Spectra and Quantum Efficiency}

The PL excitation (PLE) was monitored at $458 \mathrm{~nm}$, and the PL emission spectra were obtained under $\lambda_{\mathrm{ex}}=350 \mathrm{~nm}$ as an excitation wavelength. Although the Eu ions were introduced from a strong nitric acid solution during the synthetic process, this acid may cause traces of transition metal ions impurities $(\mathrm{Cr}, \mathrm{Cu}, \mathrm{Pb}, \mathrm{Ni}, \mathrm{Zn}, \mathrm{Au}, \mathrm{Ti})$. However, these are negligible due to the very low concentration in the whole solution $(<0.01 \mathrm{ppm})$. If all transition metals are present in the phosphor powders, the concentration would be $\sim 0.1 \mathrm{ppb}$, which would not influence the luminescence properties. Figure 7a-c shows the PLE spectra (dashed lines) with a broadband absorption in the near UV region from $200 \mathrm{~nm}$ to $400 \mathrm{~nm}$, with a maximum at $350 \mathrm{~nm}$, which is attributed to the allowed transition of 
$\mathrm{Eu}^{2+}$. The PL emission (solid lines) shows a spectrum with a maximum at $458 \mathrm{~nm}$, which corresponds to the parity allowed $4 f^{6} 5 d^{1} \rightarrow 4 f^{7}$ transition of $\mathrm{Eu}^{2+}$. In Figure $7 \mathrm{a}$, the absorption and emission intensities, together with the quantum efficiency $(\Phi)$, increased with the increase of the amount of $\mathrm{NH}_{4} \mathrm{~F}$. A maximum $\Phi$ of $17 \%$ was found at 11 wt.\% of $\mathrm{NH}_{4} \mathrm{~F}$. For the $\mathrm{NH}_{4} \mathrm{Cl}$ flux (Figure $7 \mathrm{~b}$ ), the quantum efficiency increased from $5 \%$ to $11 \%$ when $2 \mathrm{wt} . \%$ of $\mathrm{NH}_{4} \mathrm{Cl}$ was added. For the amounts of $\mathrm{NH}_{4} \mathrm{Cl}>2$ wt. $\%$, $\Phi$ decreased. As shown in Figure $7 \mathrm{c}, \Phi$ with $\mathrm{H}_{3} \mathrm{BO}_{3}$ was very low, $\sim 1 \%$, because of the significant amount of $\mathrm{SiO}_{2}$ in the sample, as was confirmed by the XRD (Figure 3b). Figure 7d is a plot of $\Phi$ as a function of the amount of flux for all three fluxes used in the current study. A cumulative analysis of Figures $2 \mathrm{c}$ and $7 \mathrm{~d}$ demonstrates that the change in the crystallite sizes of the materials produced with $\mathrm{NH}_{4} \mathrm{~F}$ and $\mathrm{NH}_{4} \mathrm{Cl}$ fluxes, directly relates to the change in their corresponding quantum efficiencies [35]. For 0-10 wt.\% of $\mathrm{NH}_{4} \mathrm{~F}$, the average crystallite size increased from $13 \mathrm{~nm}$ to $31 \mathrm{~nm}$, and the corresponding quantum efficiencies improved from $5 \%$ to $17 \%$. Similarly, for $0 \mathrm{wt} . \%, 2 \mathrm{wt} . \%$, $6 \mathrm{wt} . \%$, and $10 \mathrm{wt} . \%$, of the $\mathrm{NH}_{4} \mathrm{Cl}$ flux, the average crystallite sizes were $13 \mathrm{~nm}, 19 \mathrm{~nm}, 15 \mathrm{~nm}$, $18 \mathrm{~nm}$, respectively, and the corresponding quantum efficiencies showed similar trend. In constant, with $0-10 \mathrm{wt} . \%$ of $\mathrm{H}_{3} \mathrm{BO}_{3}$, the crystallite size increased from $\sim 13 \mathrm{~nm}$ to $\sim 27 \mathrm{~nm}$, but the quantum efficiency was low due to the presence of a large fraction of the secondary phase, $\mathrm{SiO}_{2}$.

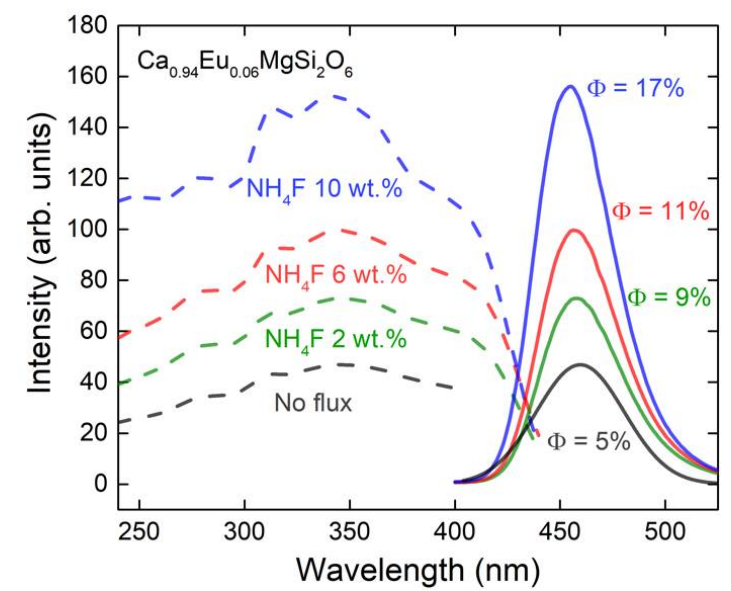

(a)

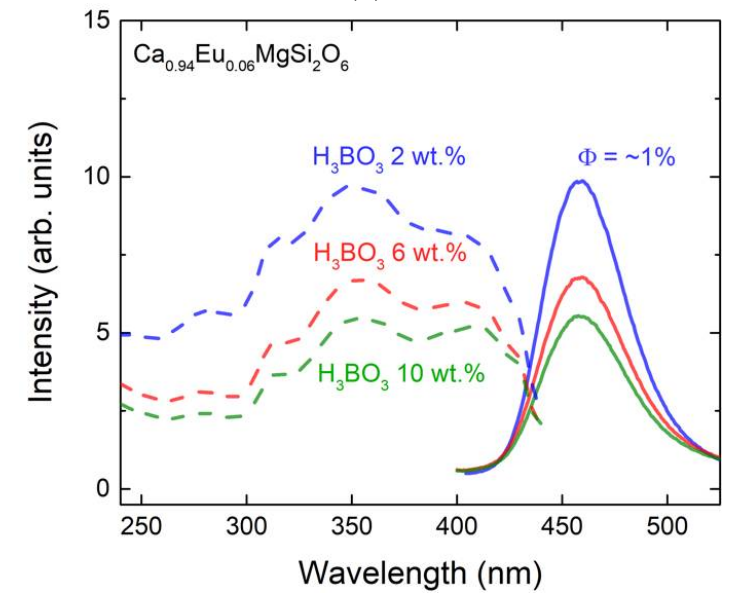

(c)

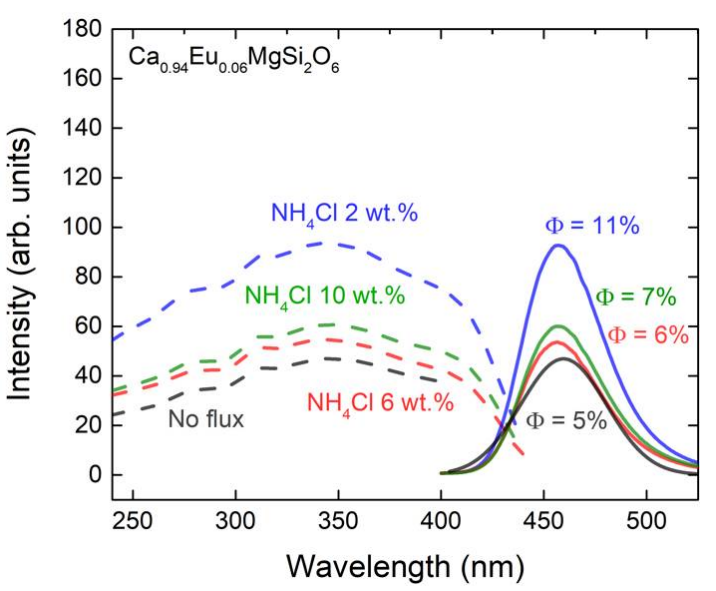

(b)

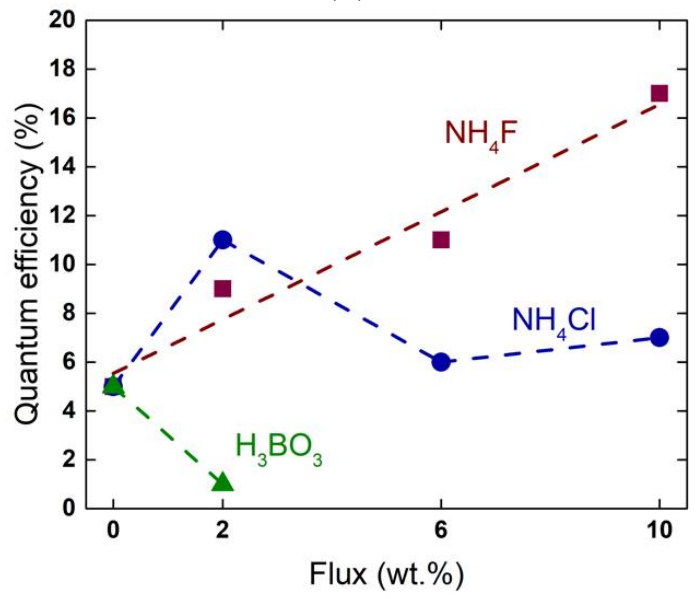

(d)

Figure 7. Photoluminescence excitation (dashed line monitored at $458 \mathrm{~nm}$ ) and emission (solid line, $\lambda_{\text {ex }}=350 \mathrm{~nm}$ ) spectra of $\mathrm{Ca}_{0.94} \mathrm{Eu}_{0.06} \mathrm{MgSi}_{2} \mathrm{O}_{6}$ with (a) $\mathrm{NH}_{4} \mathrm{~F}$ (no flux, 2 wt. $\%$, 6 wt. $\%$, and 10 wt. $\%$ ); (b) $\mathrm{NH}_{4} \mathrm{Cl}$ (no flux, 2 wt.\%, 6 wt.\%, and 10 wt.\%); (c) $\mathrm{H}_{3} \mathrm{BO}_{3}$ (2 wt.\%, 6 wt.\%, and 10 wt.\%). $\Phi=$ quantum efficiency; (d) The relationship between quantum efficiency and the amount of flux. 


\subsection{Effect of High Concentration of $\mathrm{NH}_{4} \mathrm{Cl}$}

Increased amount of $\mathrm{NH}_{4} \mathrm{Cl}$ was examined to determine if the high concentration of this particular flux resulted in the formation of second phase, a change in crystal structure, or further improvement of $\Phi$ while phosphors with $\mathrm{NH}_{4} \mathrm{~F}$ and $\mathrm{H}_{3} \mathrm{BO}_{3}$ already consist of secondary phases below $10 \mathrm{wt} . \%$ of the flux. Figure $8 \mathrm{a}$ shows the XRD patterns of $\mathrm{CaMgSi}_{2} \mathrm{O}_{6}$ produced with 14, 17, and $20 \mathrm{wt} . \%$ of $\mathrm{NH}_{4} \mathrm{Cl}$ flux. There were no secondary phases with 14 and $17 \mathrm{wt} . \%$, but $\mathrm{CaSiO}_{3}$ was detected for $20 \mathrm{wt} . \%$ of $\mathrm{NH}_{4} \mathrm{Cl}$. The lattice parameters $a$ and $c$ were not affected, but $b$ decreased from $0.8867 \mathrm{~nm}$ (for $14 \mathrm{wt} . \%$ ) to $0.8852 \mathrm{~nm}$ (for $20 \mathrm{wt} . \%$ ) (Figure $8 \mathrm{~b}$ ). Given that the radii difference between $\mathrm{Cl}^{-}$and $\mathrm{O}^{2-}$ is $26 \%$, excessive $\mathrm{Cl}^{-}$may substitute for $\mathrm{O}^{2-}$ and produce a charge imbalance. This could cause cation defects and/or the creation of secondary phases such as $\mathrm{CaSiO}_{3} \cdot \mathrm{MgSiO}_{3}$ could also potentially be produced due to the substitution $\mathrm{O}^{2-}$ by $\mathrm{Cl}^{-}$, but it was not detected by XRD. Vegard's law can also be applied to the $b$-axis change, with an assumption that there are vacancy defects of $\frac{1}{2} \mathrm{Ca}^{2+}, \frac{1}{2} \mathrm{Mg}^{2+}$ or $\frac{1}{4} \mathrm{Si}^{4+}$ due to the charge difference between $\mathrm{O}^{2-}$ and $\mathrm{Cl}^{-}$. To obtain the maximum difference between $b$ and $b_{0}$, $\mathrm{Ca}^{2+}$ vacancies were assumed. The lattice parameter change is $b=b_{0}-\frac{1}{2} x r_{C a}-x\left(r_{O}-r_{C l}\right)$, where $b$ is the lattice parameter $(0.8852 \mathrm{~nm})$ with $20 \mathrm{wt} . \% \mathrm{Cl}^{-}$additions, $b_{0}$ is the initial lattice parameter with no flux $(0.8900 \mathrm{~nm}), x$ is the partial substitution of $\mathrm{Cl}^{-}$on $\mathrm{O}^{2-}$, and $r_{\mathrm{Ca}}, r_{\mathrm{Si}}, r_{\mathrm{O}}, r_{\mathrm{Cl}}$ are radii of $\mathrm{Ca}^{2+}$, $\mathrm{Si}^{4+}, \mathrm{O}^{2-}$, and $\mathrm{Cl}^{-}$, respectively. The obtained $x$ value is 0.32 , which is smaller than the molar fraction of $\mathrm{Cl}^{-}$in $\mathrm{CaMgSi}_{2} \mathrm{O}_{6}\left(0.50\right.$, converted from $20 \mathrm{wt}$. $\left.\% \mathrm{NH}_{4} \mathrm{Cl}\right)$. The remaining $\mathrm{Cl}^{-}$is likely from the excessive addition of $\mathrm{NH}_{4} \mathrm{Cl}$. The crystal structure along the [001] (Figure 1d) and [010] (Figure 1c) directions shows one $\mathrm{Ca}^{2+}$ and one $\mathrm{Mg}^{2+}$ along the $a$ - and $c$-axes and two $\mathrm{Ca}^{2+}$ and two $\mathrm{Mg}^{2+}$ along the $b$-axis, resulting in the fraction of $\mathrm{Mg}^{2+}$ and $\mathrm{Ca}^{2+}$ along the $b$-axis being twice higher than that along the $a$ - and $c$-axes. Therefore, the $b$-axis was altered more than the $a$ - and $c$-axes.

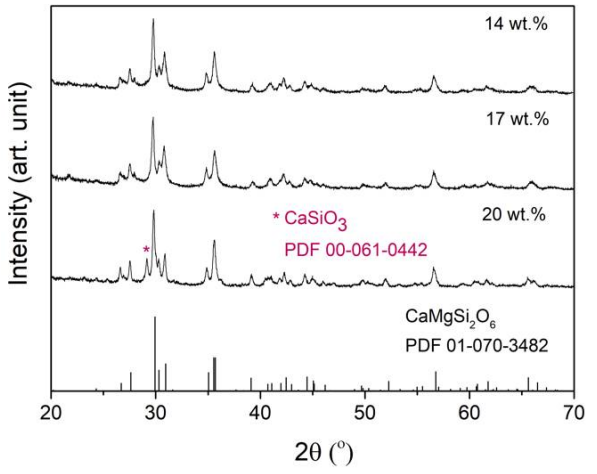

(a)

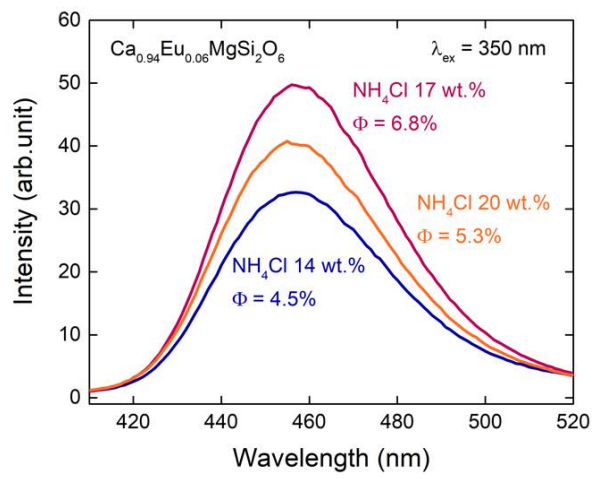

(c)

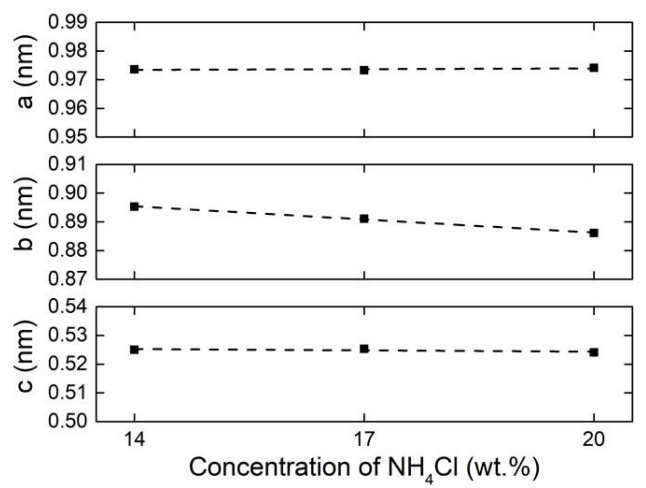

(b)

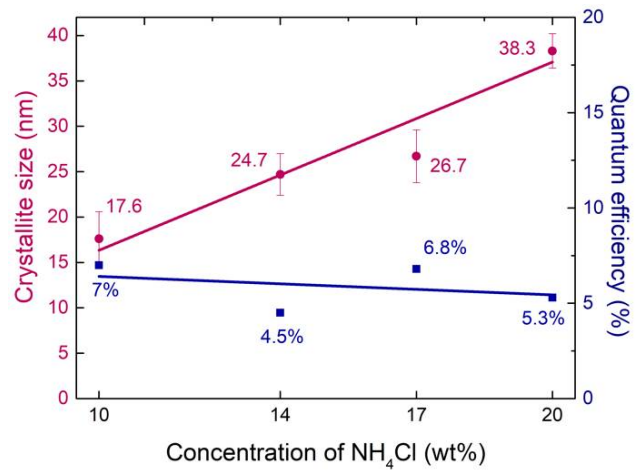

(d)

Figure 8. Effect of additional $\mathrm{NH}_{4} \mathrm{Cl}$ flux (14 wt.\%, 17 wt.\%, and 20 wt.\%) on $\mathrm{CaMgSi}_{2} \mathrm{O}_{6}: \mathrm{Eu}^{2+}$. (a) X-ray diffraction patterns; (b) calculated lattice parameters of $\mathrm{CaMgSi}_{2} \mathrm{O}_{6}: \mathrm{Eu}^{2+}$; (c) photoluminescence emission spectra $\left(\lambda_{\mathrm{ex}}=350 \mathrm{~nm}\right)$ and quantum efficiencies $(\mathbf{d})$ calculated crystallite sizes (pink color) and quantum efficiencies (blue color) from 0 to $20 \mathrm{wt} \% \mathrm{NH}_{4} \mathrm{Cl}$. 
The PL emission spectra and $\Phi$ s with additional $\mathrm{NH}_{4} \mathrm{Cl}$ flux are shown in Figure $8 \mathrm{c}$. The $\Phi$ s were not significantly changed with an increase in the amount of $\mathrm{NH}_{4} \mathrm{Cl}$. A comparison between crystallite size and $\Phi$ s with the amount of $\mathrm{NH}_{4} \mathrm{Cl}$ flux is shown in Figure $8 \mathrm{~d}$. The maximum $\Phi$ corresponded to $2 \mathrm{wt} . \%$; over $2 \mathrm{wt} . \% \Phi$ initially decreased and eventually leveled off. However, the crystallite sizes increased with an increase in the concentration of the flux. This implies that the flux, although increasing the crystallite size, also changed lattice parameters resulting in no enhancement of $\Phi$ due to the inappropriate amount of flux addition.

\section{Conclusions}

The crystallite size and quantum efficiency of blue-emitting $\mathrm{Ca}_{0.94} \mathrm{Eu}_{0.06} \mathrm{MgSi}_{2} \mathrm{O}_{6}$ submicrometersized phosphors prepared by the co-precipitation method were altered with the addition of a flux, $\mathrm{NH}_{4} \mathrm{~F}, \mathrm{NH}_{4} \mathrm{Cl}$, or $\mathrm{H}_{3} \mathrm{BO}_{3}$. The particle sizes both with and without fluxes $\left(\mathrm{NH}_{4} \mathrm{~F}\right.$ or $\left.\mathrm{NH}_{4} \mathrm{Cl}\right)$ were submicrometer-sized $(\sim 100 \mathrm{~nm})$. A direct correlation between crystallite sizes of the materials produced with $\mathrm{NH}_{4} \mathrm{~F}$ or $\mathrm{NH}_{4} \mathrm{Cl}$ fluxes and their corresponding quantum efficiencies was verified. For the $\mathrm{NH}_{4} \mathrm{~F}$ flux, the crystallite size increased from $13 \mathrm{~nm}$ (no flux) to $31 \mathrm{~nm}$ (10 wt.\% flux). The corresponding quantum efficiencies improved from $5 \%$ (no flux) to $17 \%$ (10 wt. $\%$ flux), correlating with the increase in crystallite size. For the $\mathrm{NH}_{4} \mathrm{Cl}$ flux, the crystallite sizes increased to $18 \mathrm{~nm}$ with $10 \mathrm{wt} . \%$ from $13 \mathrm{~nm}$ with no flux, with a corresponding increase in quantum efficiency from $5 \%$ to $11 \%$. This demonstrates that $\mathrm{NH}_{4} \mathrm{Cl}$ is not an effective flux, likely due to its lower liquid diffusion coefficient compared to $\mathrm{NH}_{4} \mathrm{~F}$. Additionally, it was shown that further increasing the amount of the $\mathrm{NH}_{4} \mathrm{Cl}$ flux (14-20 wt.\%) only slightly improved the corresponding quantum efficiency. The $\mathrm{H}_{3} \mathrm{BO}_{3}$ flux produced a substantial amount of $\mathrm{SiO}_{2}$ as a secondary phase, which negatively affected the quantum efficiency of the resultant material. From lattice parameter measurements, it is shown that the phosphor was contaminated with boron ions, and silicon was leached out of the lattice.

In summary, it is shown that the poor quantum efficiency of submicron-sized phosphors can be improved by using $\mathrm{NH}_{4} \mathrm{~F}$ flux for $\mathrm{CaMgSi}_{2} \mathrm{O}_{6}: \mathrm{Eu}^{2+}$, but the flux composition and amount must be carefully assessed to evaluate the presence of secondary phases.

Author Contributions: Conceptualization, J.H. and J.M.; Methodology, J.H., C.Z.; Software, J.H.; Validation, E.N., O.A.G., and J.M.; Formal Analysis, J.H., E.N., R.E.R., and J.M.; Investigation, J.M.; Resources, O.A.G., G.A.H., J.M.; Data Curation, J.H., E.N., J.M.; Writing-Original Draft Preparation, J.H.; Writing-Review \& Editing, E.N., O.A.G., and J.M.; Visualization, J.H.; Supervision, J.M.; Project Administration, J.M.; Funding Acquisition, J.M.

Funding: This research was funded by [the National Science Foundation, Ceramics Program] grant number [Grant DMR-1411192].

Acknowledgments: This work is supported by the National Science Foundation, Ceramics Program Grant DMR-1411192. This work was performed in part at the San Diego Nanotechnology Infrastructure (SDNI) of UCSD, a member of the National Nanotechnology Coordinated Infrastructure, which is supported by the National Science Foundation (Grant ECCS-1542148).

Conflicts of Interest: The authors declare no conflicts of interest.

\section{References}

1. Blasse, G.; Grabmaier, B.C. Luminescent Materials; Springer: Berlin/Heidlberg, Germany, 1994.

2. Han, J.K.; Choi, J.I.; Piquette, A.; Hannah, M.; Anc, M.; Galvez, M.; Talbot, J.B.; McKittrick, J. Phosphor development and integration for near-UV LED solid state lighting. ECS J. Solid State Sci. Technol. 2012, 2, R3138-R3147. [CrossRef]

3. Luo, H.; Liu, J.; Zheng, X.; Han, L.; Ren, K.; Yu, X. Enhanced photoluminescence of $\mathrm{Sr}_{3} \mathrm{SiO}_{5}: \mathrm{Ce}^{3+}$ and tuneable yellow emission of $\mathrm{Sr}_{3} \mathrm{SiO}_{5}: \mathrm{Ce}^{3+}, \mathrm{Eu}^{2+}$ by $\mathrm{Al}^{3+}$ charge compensation for W-LEDs. J. Mater. Chem. 2012, 22, 15887-15893. [CrossRef]

4. Lee, S.H.; Choi, J.I.; Kim, Y.J.; Han, J.K.; Ha, J.; Novitskaya, E.; Talbot, J.B.; McKittrick, J. Comparison of luminescent properties of $\mathrm{Y}_{2} \mathrm{O}_{3}: \mathrm{Eu}^{3+}$ and $\mathrm{LaPO}_{4}: \mathrm{Ce}^{3+}, \mathrm{Tb}^{3+}$ phosphors prepared by various synthetic methods. Mater. Charact. 2015, 103, 162-169. [CrossRef] 
5. Terraschke, H.; Wickleder, C. UV, blue, green, yellow, red, and small: Newest developments on Eu-doped nanophosphors. Chem. Rev. 2015, 115, 11352-11378. [CrossRef] [PubMed]

6. Jung, K.Y.; Lee, C.H.; Kang, Y.C. Effect of surface area and crystallite size on luminescent intensity of $\mathrm{Y}_{2} \mathrm{O}_{3}: \mathrm{Eu}$ phosphor prepared by spray pyrolysis. Mater. Lett. 2005, 59, 2451-2456. [CrossRef]

7. Chiang, C.H.; Liu, T.H.; Lin, H.Y.; Kuo, H.Y.; Chu, S.Y. Effects of flux additives on the characteristics of $\mathrm{Y}_{2.95} \mathrm{Al}_{5} \mathrm{O}_{12}: 0.05 \mathrm{Ce}^{3+}$ phosphor: Particle growth mechanism and luminescence. J. Appl. Phys. 2013, 114, 243517. [CrossRef]

8. Zhang, Q.; Ni, H.; Wang, L.; Xiao, F. Effects of $\mathrm{BaF}_{2}$ flux on the synthesis of green emitting phosphor $\mathrm{CaSc}_{2} \mathrm{O}_{4}: \mathrm{Ce}^{3+}$. ECS J. Solid State Sci. Technol. 2014, 4, R23-R26. [CrossRef]

9. Dai, P.; Zhang, X.; Sun, P.; Yang, J.; Wang, L.; Yan, S.; Liu, Y.; Ballato, J. Influence of flux on morphology and luminescence properties of phosphors: A case study on $\mathrm{Y}_{1.55} \mathrm{Ti}_{2} \mathrm{O}_{7}: 0.45 \mathrm{Eu}^{3+}$. J. Am. Ceram. Soc. 2012, 95, 1447-1453. [CrossRef]

10. Lee, G.-H.; Yoon, C.; Kang, S. Role of flux in the production process of red phosphors for white LEDs. J. Mater. Sci. 2008, 43, 6109-6115. [CrossRef]

11. Pamplin, B.R. Crystal Growth, 2nd ed.; Pergamon Press: Beccles/London, UK, 1980.

12. Stoll, S.L.; Stacy, A.M. Single-crystal growth, alkali metal ordering, and superconductivity in $\mathrm{La}_{2-\mathrm{x}} \mathrm{M}_{\mathrm{x}} \mathrm{CuO}_{4}$ $(\mathrm{M}=\mathrm{Na}, \mathrm{K})$. Inorg. Chem. 1994, 33, 2761-2765. [CrossRef]

13. Chen, Y.B.; Gong, M.L.; Cheah, K.W. Effects of fluxes on the synthesis of $\mathrm{Ca}_{3} \mathrm{Sc}_{2} \mathrm{Si}_{3} \mathrm{O}_{12}: \mathrm{Ce}^{3+}$ green phosphors for white light-emitting diodes. Mater. Sci. Eng. B Adv. Funct. Solid State Mater. 2010, 166, 24-27. [CrossRef]

14. Tang, J.Y.; He, Y.M.; Hao, L.Y.; Xu, X.; Agathopoulos, S. Fine-sized $\mathrm{BaSi}_{3} \mathrm{Al}_{3} \mathrm{O}_{4} \mathrm{~N}_{5}$ :Eu ${ }^{2+}$ phosphors prepared by solid-state reaction using $\mathrm{BaF}_{2}$ flux. J. Mater. Res. 2013, 28, 2598-2604. [CrossRef]

15. Wang, X.; Li, J.H.; Shi, P.L.; Guan, W.M.; Zhang, H.Y. High dispersibility and enhanced luminescence properties of $\mathrm{BaMgAl}_{10} \mathrm{O}_{17}: \mathrm{Eu}^{2+}$ phosphors derived from molten salt synthesis. Opt. Mater. 2015, 46, 432-437. [CrossRef]

16. Liu, J.Q.; Wang, X.J.; Xuan, T.T.; Wang, C.B.; Li, H.L.; Sun, Z. $\mathrm{Lu}_{3}(\mathrm{Al}, \mathrm{Si})_{5}(\mathrm{O}, \mathrm{N})_{12}$ :Ce ${ }^{3+}$ phosphors with broad emission band and high thermal stability for white LEDs. J. Lumin. 2015, 158, 322-327. [CrossRef]

17. Dong, K.; Li, Z.L.; Xiao, S.G.; Xiang, Z.F.; Zhang, X.A.; Yang, X.L.; Jin, X.L. Yellowish-orange luminescence in $\mathrm{Sr}_{8} \mathrm{Al}_{12} \mathrm{O}_{24} \mathrm{~S}_{2}: \mathrm{Eu}^{2+}$ phosphor. J. Alloys Compd. 2012, 543, 105-108. [CrossRef]

18. Lee, S.H.; Jung, D.S.; Han, J.M.; Koo, H.Y.; Kang, Y.C. Fine-sized $\mathrm{Y}_{3} \mathrm{Al}_{5} \mathrm{O}_{12}$ :Ce phosphor powders prepared by spray pyrolysis from the spray solution with barium fluoride flux. J. Alloys Compd. 2009, 477, 776-779. [CrossRef]

19. Kang, H.S.; Kang, Y.C.; Jung, K.Y.; Park, S.B. Eu-doped barium strontium silicate phosphor particles prepared from spray solution containing $\mathrm{NH}_{4} \mathrm{Cl}$ flux by spray pyrolysis. Mater. Sci. Eng. B Solid State Mater. Adv. Technol. 2005, 121, 81-85. [CrossRef]

20. Wang, J.S.; Zhu, D.-C.; Zheng, Q.; Han, T. Effect of flux on the composition and luminescent properties of $\mathrm{Ca}_{0.68} \mathrm{Mg}_{0.2} \mathrm{SiO}_{3}: 0.12 \mathrm{Eu}^{3+}$ red phosphor. J. Lumin. 2016, 179, 183-188. [CrossRef]

21. Zhang, B.; Feng, L.; Qiang, Y. Preparation and photoluminescence properties of the $\mathrm{Sr}_{1.56} \mathrm{Ba}_{0.4} \mathrm{SiO}_{4}: 0.04 \mathrm{Eu}^{2+}$ phosphor. J. Lumin. 2012, 132, 1274-1277. [CrossRef]

22. Pires, A.M.; Davolos, M.R. Luminescence of europium (III) and manganese (II) in barium and zinc orthosilicate. Chem. Mater. 2001, 13, 21-27. [CrossRef]

23. Pawar, A.U.; Jadhav, A.P.; Pal, U.; Kim, B.K.; Kang, Y.S. Blue and red dual emission nanophosphor $\mathrm{CaMgSi}_{2} \mathrm{O}_{6}: \mathrm{Eu}^{\mathrm{n}+}$; crystal structure and electronic configuration. J. Lumin. 2012, 132, 659-664. [CrossRef]

24. Ha, J.; Wang, Z.; Novitskaya, E.; Hirata, G.A.; Graeve, O.A.; Ong, S.P.; McKittrick, J. An integrated first principles and experimental investigation of the relationship between structural rigidity and quantum efficiency in phosphors for solid state lighting. J. Lumin. 2016, 179, 297-305. [CrossRef]

25. Cahill, J.T.; Ruppert, J.N.; Wallis, B.; Liu, Y.; Graeve, O.A. Development of mesoporosity in scandia-stabilized zirconia: Particle size, solvent, and calcination effects. Langmuir 2014, 30, 5585-5591. [CrossRef] [PubMed]

26. Graeve, O.A.; Fathi, H.; Kelly, J.P.; Saterlie, M.S.; Sinha, K.; Rojas-George, G.; Kanakala, R.; Brown, D.R.; Lopez, E.A. Reverse micelle synthesis of oxide nanopowders: Mechanisms of precipitate formation and agglomeration effects. J. Colloid Interface Sci. 2013, 407, 302-309. [CrossRef] [PubMed]

27. Saterlie, H.S.M.S.; Kavlicoglu, B.; Liu, Y.; Graeve, O.A. Surfactant effects on dispersion characteristics of copper-based nanofluids: A dynamic light scattering study. Chem. Mater. 2012, 24, 3299-3306. [CrossRef] 
28. Momma, K.; Izumi, F. VESTA: A three-dimensional visualization system for electronic and structural analysis. J. Appl. Crystallogr. 2008, 41, 653-658. [CrossRef]

29. Knyazev, A.V.; Bulanov, E.N.; Korshunov, A.O.; Krasheninnikova, O.V. Synthesis and thermal expansion of some lanthanide-containing apatites. Inorg. Mater. 2013, 49, 1133-1137. [CrossRef]

30. Shannon, R.D. Revised effective ionic radii and systematic studies of interatomie distances in halides and chaleogenides. Acta Crystallogr. Sect. A Cryst. Phys. Diffr. Theor. Gen. Crystallogr. 1976, 32, 751-767. [CrossRef]

31. Marler, B.; Borowski, M.; Wodara, U.; Schreyer, W. Synthetic tourmaline (olenite) with excess boron replacing silicon in the tetrahedral site: II. Structure analysis. Eur. J. Mineral. 2002, 14, 763-771. [CrossRef]

32. Xia, Z.; Molokeev, M.S.; Im, W.B.; Unithrattil, S.; Liu, Q. Crystal structure and photoluminescence evolution of $\mathrm{La}_{5}\left(\mathrm{Si}_{2+\mathrm{x}} \mathrm{B}_{1-\mathrm{x}}\right)\left(\mathrm{O}_{13-\mathrm{x}} \mathrm{N}_{\mathrm{x}}\right): \mathrm{Ce}^{3+}$ solid solution phosphors. J. Phys. Chem. C 2015, 119, 9488-9495. [CrossRef]

33. Denton, A.R.; Ashcroft, N.W. Vegard's law. Phys. Rev. A 1991, 43, 3161-3164. [CrossRef] [PubMed]

34. Prencipe, D.D.I.; Zani, A.; Rizzo, D.; Passoni, M. Energy dispersive X-ray spectroscopy for nanostructured thin film density evaluation. Sci. Technol. Adv. Mater. 2015, 16, 025007. [CrossRef] [PubMed]

35. Dantelle, G.; Salaün, M.; Bruyère, R.; Kodjikian, S.; Ibanez, A. Luminescent coatings prepared from optimized YAG:Ce nanoparticles. Thin Solid Films 2017, 643, 36-42. [CrossRef]

(C) 2018 by the authors. Licensee MDPI, Basel, Switzerland. This article is an open access article distributed under the terms and conditions of the Creative Commons Attribution (CC BY) license (http:/ / creativecommons.org/licenses/by/4.0/). 